Portland State University

PDXScholar

\title{
An Exploratory Inquiry into Community Policing Using Focus Groups: Perspectives from Social Service Providers
}

Tanya Leigh Ostrogorsky

Portland State University

Follow this and additional works at: https://pdxscholar.library.pdx.edu/open_access_etds

Part of the Criminal Law Commons, and the Legal Studies Commons

Let us know how access to this document benefits you.

\section{Recommended Citation}

Ostrogorsky, Tanya Leigh, "An Exploratory Inquiry into Community Policing Using Focus Groups: Perspectives from Social Service Providers" (1996). Dissertations and Theses. Paper 5151. https://doi.org/10.15760/etd.7027

This Thesis is brought to you for free and open access. It has been accepted for inclusion in Dissertations and Theses by an authorized administrator of PDXScholar. Please contact us if we can make this document more accessible: pdxscholar@pdx.edu. 


\section{THESIS APPROVAL}

The abstract and thesis of Tanya Leigh Ostrogorsky for the Master of Science in Administration of Justice was presented August 22, 1996, and accepted by the thesis committee and the department. COMMITTEE APPROVALS:
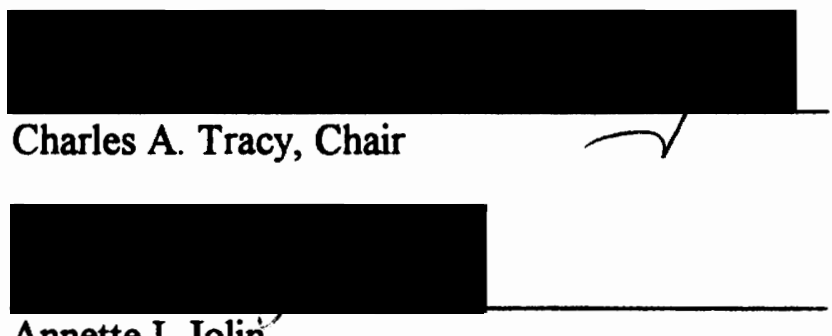

Annette I. Jolin

DEPARTMENT APPROVAL:

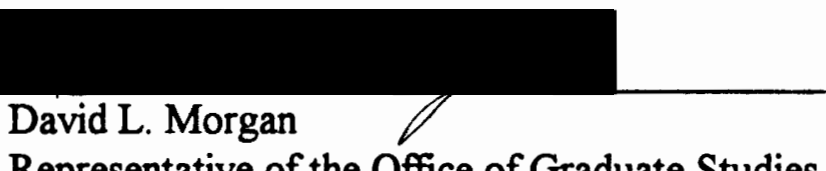

Representative of the Office of, Graduate Studies

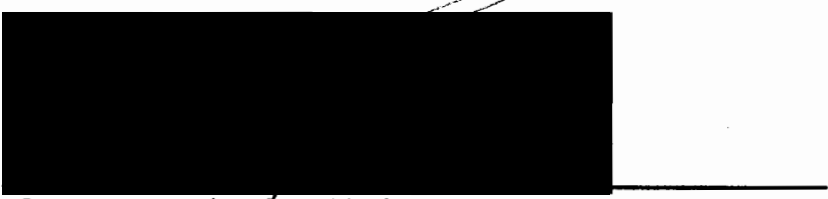

Gary R. Perlsteín, Chair

Department of Administration of Justice

ACCEPTED FOR PORTLAND STATE UNIVERSITY BY THE LIBRARY

by on

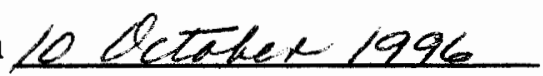




\begin{abstract}
An abstract of the thesis of Tanya Leigh Ostrogorsky for the Master of Science in Administration of Justice presented August 22, 1996.
\end{abstract}

Title: An Exploratory Inquiry Into Community Policing Using Focus Groups: Perspectives From Social Service Providers.

The purpose of this study was to evaluate Portland, Oregon's community policing policy by using focus groups to discuss the development and effectiveness over one year, Spring 1994 to Spring 1995. The group discussed included management level social service providers and was one piece of a large scale program evaluation. The collected data developed into six major categories: 1) personnel policies and institutional memory; 2) training; 3) consistency; 4) community involvement and responsibility; 5) partnerships or relationships, and 6) change over time. The most highly discussed issue was the discrepancy between the philosophy of the Bureau, community policing, and the way in which the Bureau moves personnel. Data analysis suggested that the level of confidence and support felt by social service providers has increased dramatically over one year. Although, the group participants still have many issues they would like to see resolved, all recognize this is a process that takes time. Generally, community policing has rooted itself and established a footing with the social service providers who are committed to assisting in the molding and development of community policing as well as providing resources to assist in that journey. 


\title{
AN EXPLORATORY INQUIRY INTO COMMUNITY POLICING USING FOCUS GROUPS: PERSPECTIVES FROM SOCIAL SERVICE PROVIDERS
}

\author{
by \\ TANYA LEIGH OSTROGORSKY
}

A thesis submitted in partial fulfillment of the requirements for the degree of

\author{
MASTER OF SCIENCE \\ in \\ ADMINISTRATION OF JUSTICE
}

Portland State University

1996 


\section{Table of Contents}

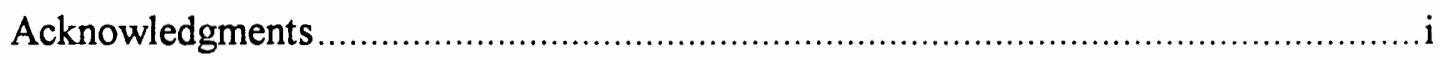

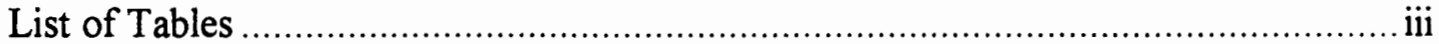

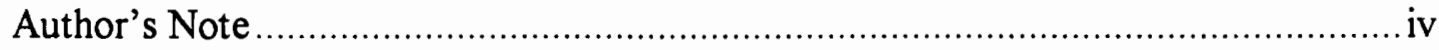

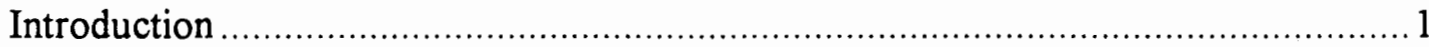

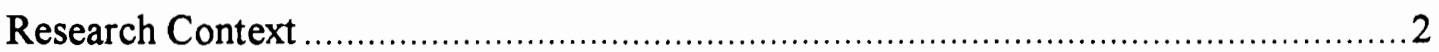

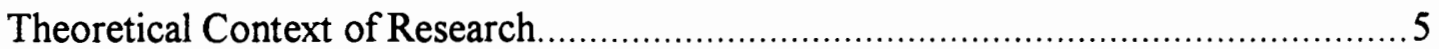

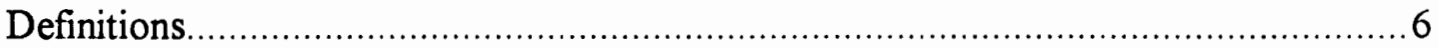

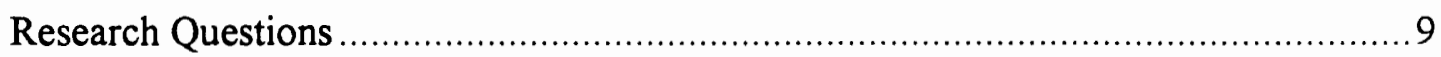

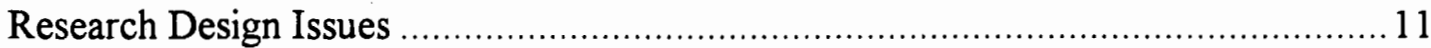

Appropriateness of Qualitative Methodology ……...................................... 11

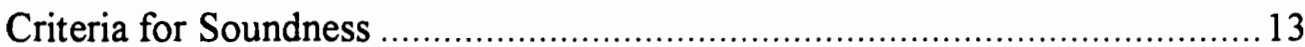

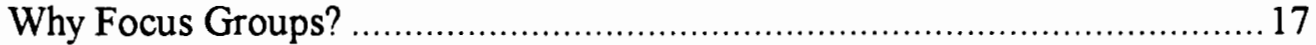

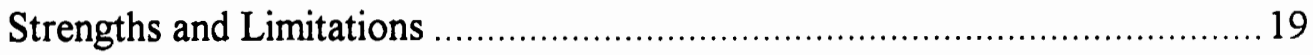

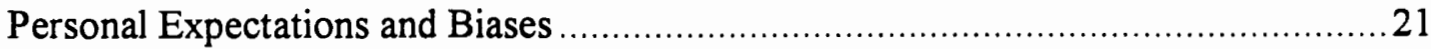

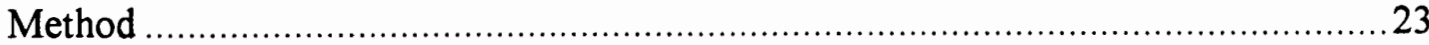

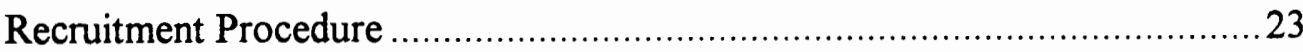

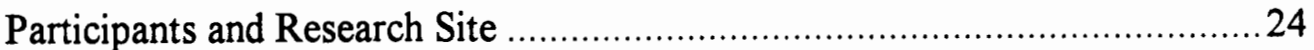

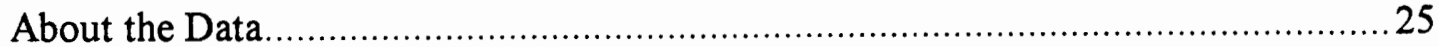

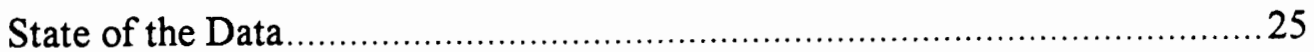




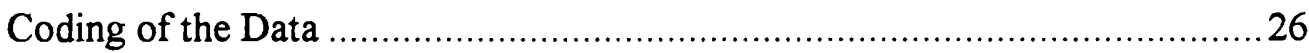

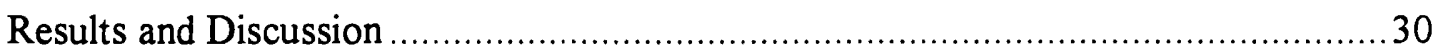

Personnel Policies and Institutional Memory ...............................................30

Training

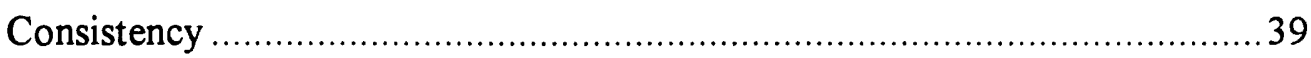

Community Involvement and Responsibility ……....................................42

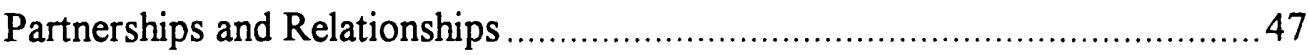

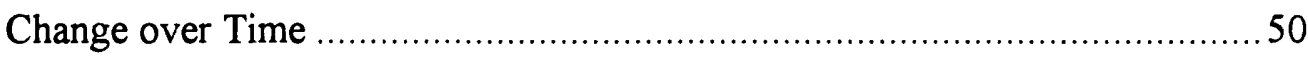

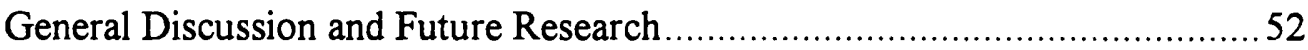

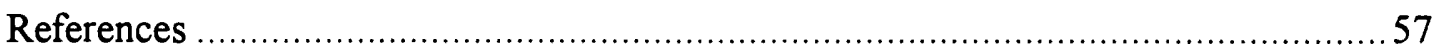

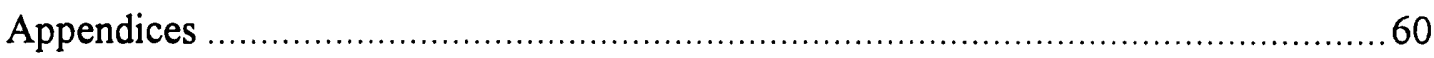

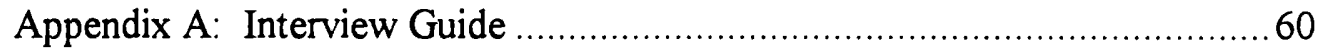

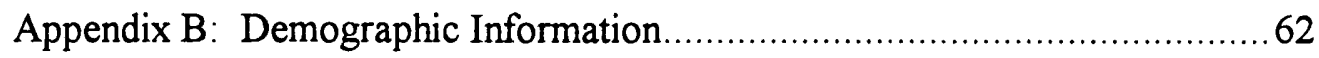

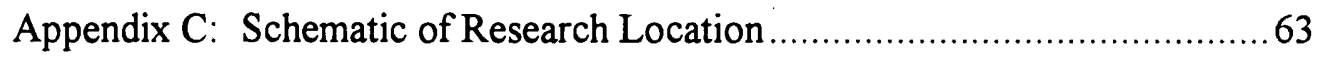

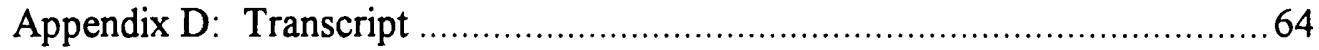

Appendix E: Schematic of Personnel Change Issue ………........................92 


\section{Acknowledgments}

There were times when I thought this day would never come and the process I have been through not only taught me who I am, but has helped me to see other people more clearly. While the process was sometimes painful I have taken all that I have experienced in hope that I have become a better person for it.

My first acknowledgment goes to my husband, Ken. Without his ever-present support and encouragement this day would still be in the future for me. He has been through the frustrations, the breakthroughs, the uncertainty and self doubt. He has pushed me forward when all I wanted to do was stop, he made me laugh when I wanted to cry, he filled me with confidence when I was feeling low. For that, I thank him from the depth of my heart and say, "One more to go!"

Next, I want to thank my parents for their support in this endeavor. I want to thank them for the undergraduate education that provided me with the skills to get to where I am today. I want to thank my Mom for the hours she spent checking grammar, reworking sentence structure, and learning more about Portland's community policing project than she ever wanted to know. I want to thank my Dad for helping me laugh at myself and always being there with a supporting word.

I also want to thank a high school teacher that has been influential in my life. Linda Heller helped me develop my writing skills and have confidence in what I wrote. Her words over the years have helped me continue writing and believing in my ability. Thank you so much Mrs. Heller from Capital High School, Boise, Idaho. 
I want to thank David Morgan for bringing my into this research project and teaching me some tricks of the trade; Charles Tracy for his flexibility, confidence, and understanding; and Annette Jolin, for her very important role on my committee.

I also want to thank Sue Poulson, my professor and friend, for believing in me and helping me in so many ways. As well, Kerth O'Brien has mentored me for the past few years and always helped to shine the light towards the end of the tunnel.

Finally, I want to thank all my friends that have helped me get to this point, particularly Nancy Carney and Maria Novak-Cronin, for their continued support over the past years, and to Angela McCulloch and Peter Buss for making the final days working on this thesis so much more fun than it would have been Thanks for being there

A Natalie Merchant song says, “...with love, with patience and with faith she'll make her way." Thanks to all who have given me what I need to get here. 
List of Tables

Table 1: Research Design for Wave I and Wave II............................................ 4

Table 2: Comparison of Scientific and Naturalistic Terminology ............................ 13

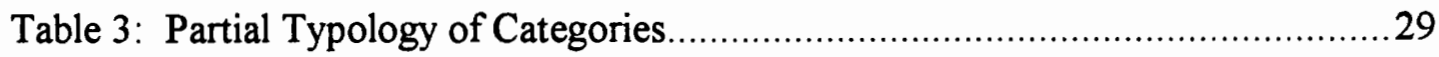




\section{Author's Note}

During the writing process I discovered that the American Psychological Association Publication Manual (4th edition) requirements for citing quotes were not written considering that users would be conducting qualitative research. To counteract this oversight, I have followed the citation procedure as indicated for quotations under forty words. However, I have added double quotations when the quotation was not edited and single quotations when editing changes were made for ease of reading when dealing with quotations over forty words. Additionally, if an APA formatting issue was different from guidelines provided by Portland State University's Graduate Studies Office, I followed the Graduate Studies Office recommendations. 
An Exploratory Inquiry into Community Policing using Focus Groups: Perspectives from Social Service Providers

The purpose of this study was to evaluate Portland, Oregon's community policing policy by using focus groups to discuss the development and effectiveness over one year, Spring 1994 to Spring 1995. This thesis will focus on one of the five focus groups in the 1995 series. The group discussed here included management level social service providers; the other groups consisted of both management and street level criminal justice agencies, street level social service providers, and youth advocates. This series was one piece of a large scale program evaluation under the joint direction of the Portland Police Bureau, University of Oregon, and Portland State University. The goal of the program evaluation was to, "develop and implement methods of measuring the performance of community policing" (Portland Police Bureau, 1995, p.1). Along with focus groups the grant-based study used a variety of surveys and group discussions with police and community members to reach this above goal. The grant's final report may be obtained from the Portland Police Bureau by requesting the Community Policing Performance Measures Final Report and Appendix (Portland Police Bureau, 1995).

In December 1988 the Portland Police Bureau (PPB) began the process of adopting community policing as their official style and philosophy for interacting with the citizens of Portland, Oregon (Austin \& Sweet, 1992, p. 62). While the adoption of community policing methods can be viewed as superior to traditional policing methods 


\section{Community Policing Page 2}

in fostering the relationships between the citizens and the police, it does have some drawbacks--primarily performance evaluation. Traditional models of policing have relied upon call response times, citations issued, warrants served, and the like to assess officer performance; however, in an environment of community policing, the measurement of quality relationship building and positive role modeling is much more abstract.

During the past decade, there have been hundreds studies that have looked into the resurgence of community policing. However, the vast majority of these studies are not rigorous scientific evaluations, but general discussions of the resurgence of community policing, descriptive accounts from police departments, or guidebooks (Pratt, 1995; Metro-Dade Police Department, 1995; Palmiotto, 1996; US Department of Justice, 1995; Teasley, 1994; Leighton, 1991; Trojanowicz \& Pollard, 1986; Bureau of Justice Assistance, 1994; Lurigio \& Rosenbaum, 1994). Furthermore, this study was the only one found that used focus groups to understand both the police department's and community's experiences with community policing. Therefore, this missing piece in the evaluation of community policing was a valuable piece of research to pursue.

\section{$\underline{\text { Research Context }}$}

To understand statements made by individuals in this group one must understand the overall context of the study. The Portland Police Bureau was awarded NIJ Grant 92-IJ-CX-K037, 
"To develop and field test community policing assessment tools to use in a community policing assessment program. This was done by examining two facets of community policing: (1) the changes that were made both in the way the organization conducts activities and the way it changes itself, and (2) the results that were achieved by making these changes" (PPB, 1995, p. 3).

One goal of the grant was to obtain information on inter-agency involvement with community policing in combination with that population's experiences and opinions. To complete that task, Dr. David Morgan of Portland State University was contracted to conduct two waves of focus groups approximately one year apart. My involvement began during the planning phase of Wave II. This involvement included being responsible for recruiting and following up with the participants, reviewing the interview guide, completing site arrangements, as well as attending all the groups. Although I was only an observer during the discussion portion of the focus groups, I actively participated in the debriefings in which Dr. Morgan and I recorded our initial reactions.

Wave I of the focus groups, conducted in Spring 1994, identified four groups as the target population: criminal justice management level; criminal justice street level; social service management level; and social service street level. For logistical reasons, the management level groups were collapsed resulting in three final groups. These groups were maintained for Wave II; however, a youth advocate group was added when it was reported to the research team that one in four calls the police responded to 
involved a juvenile (Morgan, Personal communication, February 1995). Also, the management level groups were not collapsed for Wave II. Refer to Table 1 for Wave I and Wave II research design.

Table 1

Research Design for Wave I and Wave II

\begin{tabular}{|c|c|c|}
\hline Wave I & Management Level & Street Level \\
\hline Criminal Justice Agencies & & \\
\cline { 1 - 1 } Social Service Agencies & & \\
\hline
\end{tabular}

\begin{tabular}{|r|c|c|}
\hline Wave II & Management Level & Street Level \\
\hline Criminal Justice Agencies & & \\
\hline Social Service Agencies & & \\
\hline Youth Advocates & NA & \\
\hline
\end{tabular}

As stated previously, the focus of this thesis will be on one of the five focus groups conducted in Spring 1995. The group selected involved management level social service providers and was rich in examples. Each participant had ample time to address issues as well as respond to one another's comments. In hindsight, we were able to fulfill what Morgan (1988) stated as the goal of recruiting for focus groups when he wrote, "the goal is homogeneity in background, not homogeneity in attitudes" (p. 46). 


\section{Theoretical Context of Research}

As described by Guba \& Lincoln (1994), social constructivism believes that the ontology or nature of reality is relativist, meaning that, realities are apprehendable in the form of multiple, intangible mental constructions, socially and experientially based, local and specific in nature (although elements are often shared among many individuals and even across cultures), and dependent for their form and content on the individual persons or groups holding the constructions (p. 110-111).

In layperson's terms, this means that each individual has their reality based on their experiences and perception of those experiences and that specific reality is not necessarily held by any other person. The epistemology of social constructivism, or being sure that we know what we know, is a transactional exchange of information. Within this paradigm it is assumed that the participants and the researcher are linked and, "findings are literally created as the investigation proceeds" (p. 111). This holds because within social constructivism, it is believed that the researcher is not merely an observer, but is responsible to participate in the development and understanding of the area of investigation, that participation means that the researcher must be integrated into the methodology and undergoes change as an individual during the data collection process. Finally, the methodological aspect of social constructivism is considered dialectical meaning that, "individual constructions can be elicited and refined only through interaction between and among investigator and respondents" (p. 111, italics in 
original). This means that the respondent and the researcher work together to understand and deepen one another's awareness and experience.

Considering the previous discussion, social constructivism was the most appropriate theoretical framework taking into account: 1) the definition of community policing; 2) the behaviors indicative of community policing; and 3) the effects that are seen from those behaviors. In support, I have already shown that the definition of community policing is not universal, but each individual involved with community policing has a slightly different personal understanding of what community policing is. Similarly, since the definition of community policing is fluid so are the behaviors are indicative of it. Similarly, I will show that the results seen from community policing activities are determined by the environment that they are practiced.

\section{$\underline{\text { Definitions }}$}

One difficult aspect of conducting research on community policing is the lack of a universal definition. Rosenbaum (1994) stated, "at this moment in history, there is no simple definition of community policing, either in theory or in practice" (p. xii). However, some authors have attempted to conceptually define community policing and selections follow:

"Community Policing is a new philosophy of policing, based on the concept that police officers and private citizens working together in creative ways can help solve contemporary community problems related to crime, fear of crime, social and physical disorder, and neighborhood decay. The philosophy is predicated on 
the belief that achieving goals requires that police departments develop a new relationship with law-abiding people in the community, giving them a greater voice in setting police priorities and involving them in efforts to improve the overall quality of life in their neighborhoods." (Trojanowicz \& Bucqueroux, 1990 , p. 5).

"Community policing is generally defined as 'a program that seeks to change police efforts from one of reacting to emergency calls received from community residents to one of acting in concert with residents to help prevent crime" (Teasley, 1994, from abstract).

"Community policing is not a program. [It] is a philosophy, a style and a method of providing police service and managing the police organization. The police are bonded to the community through the development of structured, working partnerships" (Vaughn, 1991, pp. 15-17).

Community policing is, "an interactive process between police officers assigned to specific beats... to mutually develop ways to identify problems and concerns and then to assess viable solutions by providing available resources from both the police department and the community to address the problems and/or concerns" (Oettmeier \& Brown, 1988, p. 126). 
"The ultimate definition of community policing is what the Department and the community agree it to be" (Montgomery County Police Department, 1991).

As the previous statements demonstrate there is a large variance in the definition of community policing. However, the recurring theme is the mutual responsibility by the community and the police force to work in conjunction with each other to prevent and solve crimes. Therefore, I will rely on the combination of the aforementioned definitions for the purposes of this thesis.

Other definitions applicable to this thesis include inter-agency involvement that referred to the level of interaction and relationship that community and private or public agencies had with each other as well as with the PPB. Criminal justice agencies were defined as public or private agencies that had formal roles in the criminal justice system or provided policing and security within the Portland metropolitan area. Examples include contracted security companies, public transportation security, school police, and sworn officers. Social service providers were broadly defined as community and non-profit agencies within the Portland metropolitan area. Examples include homeless shelters, runaway assistance programs, alcohol abuse programs, and church run outreach programs. Street level was defined as having had day to day contact with the PPB as well as the clients served by the agency. Examples include intervention specialists, gang unit officers, mental health consultants, and outreach workers. Management level reflected individuals who did not necessarily have daily contact with the PPB, but was involved in the development of programs and policies 
that influenced their agency's interaction with PPB. Examples include directors of neighborhood associations, private security supervisors, and the sheriff's office. Youth advocates were defined as individuals who worked primarily with high risk youth and had an immediate knowledge and regular interaction with the PPB. Examples of youth advocates include drop in center coordinators and workers, gang enforcement teams, court appointed custodians, as well as public and private shelters.

\section{$\underline{\text { Research Questions }}$}

The same interview guide was used for Wave I and Wave II. During Wave I the moderator followed the interview guide closely and had a structured formal interview environment. However, in Wave II the group was less structured and able to comment freely. In a focus group the moderator cannot guarantee all prepared research questions will be addressed by the group without losing some of the spontaneous interaction and communication between informants. Considering this, the prepared research questions follow. Refer to Appendix A for the complete interview guide.

1. From your point of view and your organization's, how well informed do you think you organization is about the Portland Police Bureau's community policing activities?

2. On what occasions do you or the people you work with meet with the police personnel, either one-on-one or in larger groups, to discuss specific issues and projects in the community? 
3. Does your organization have any written cooperative agreements with the Portland Police Bureau, either general or in some limited part of the city?

4. Have you or your organization seen any specific advantages from closer relations between your organization and the Police Bureau?

5. If I asked you, "What is the biggest way that community policing has affected your agency," what would you say?

6. (A) Where are things getting better and worse in regards to social disorder? (B) Thinking specifically about crime, where has that changed? What about fear of crime?

(C) Can you give me some examples of situations where the police have been involved in cooperatively identifying community problems and assisting in the resolution of those problems?

(D) Here are some terms that might describe community policing, give me your reaction to them: Open, Democratic, and Well-defined.

(E) Are you aware of any changes in the police's training that affect how they deal with you or your organization? What else could be included in their training that would improve the way they work with you?

7. If you were to point out one or two things about community policing that have changed over the past year or so what would that be?

8. Suppose we had the police chief and the mayor right here, what piece of advice would you give them about community policing? 
9. Is there anything else that you would like to tell us?

\section{Research Design Issues}

\section{Appropriateness of Qualitative Methodology}

Lincoln and Guba (1985) point out that in pursuing a qualitative research design the researcher must assure the style selected is appropriate for the questions being asked. They further say that it is, "the point of trustworthiness that the naturalistic investigator is most often attacked" (p. 294). To guard against these attacks on trustworthiness Lincoln and Guba state that, "it becomes of utmost importance that (1) the inappropriateness of the conventional criteria be well demonstrated, and (2) acceptable alternative criteria be proposed and their use defended" (p. 294).

Conventional methodology would not have been appropriate for the purposes of this project considering the research agenda. This is supported by Patton (1987) when stated that a study of innovative change calls for a dynamic approach that is process-oriented. He further stated, qualitative research methods are well suited for such an approach and that the qualitative approach permits a richer description of program implementation; an analysis of major program processes; and a description of different types of participants and different kinds of participation (p. 7, 18-19). Williams (1995) addresses the inappropriateness of conventional methods when she wrote, "quantitative methods are well suited for assessing incidents of changes, but are impractical for studying change processes that are on-going and dynamic" (p. 77). 
In response to the second challenge of trustworthiness I provide the following evidence. Marshall and Rossman (1994) state that an exploratory study, 'investigates a little understood phenomena; identifies and discovers important variables; or generates hypotheses for future research'(p. 41). All the above stated questions were goals of this study and thus, the selection of an exploratory style of investigation was proper for this project. The research strategy was also chosen considering the research team wanted to understand individual experiences with community policing that could not be captured using qualitative methods. The use of focus groups allowed the complexity and richness of the respondent's thoughts and experiences to be captured and allowed the moderator to explore issues and they arose during the group. Additionally, Marshall and Rossman (1994) support using interview techniques when the research questions include: 1) What is happening in this social program; 2) What are the salient themes, patterns, categories in participants' meaning structures?, and 3) How are these patterns linked with one another (p. 41)? All the aforementioned were important issues the research team wanted addressed and are reflected in both the interview guide and the data. As the preceding discussion points out, the specific research goals and questions answered could only be adequately captured using a qualitative approach and thus was the most appropriate methodology.

When adopting a qualitative design, not only is the methodology different from positivist approaches, but conventional terminology is no longer appropriate since the researcher is not working in a conventional environment. Lincoln \& Guba (1985) 
suggests four concepts that parallel positivist terminology that need addressed when defending a qualitative methodology: 1) truth value or credibility for internal validity; 2) applicability for external validity or generalizability; 3) consistency for reliability; and 4) neutrality for objectivity (p. 290). I have included a table by Guba (1981), reproduced with his permission, to assist in the understanding of how qualitative terminology parallels the quantitative terminology (p. 80).

Table 2

\begin{tabular}{ccc}
\hline Aspect & Scientific Term & Naturalistic Term \\
\hline \hline Truth Value & Internal Validity & Credibility \\
Applicability & External Validity & Transferability \\
& Generalizability & \\
Consistency & Reliability & Dependability \\
\hline
\end{tabular}

These concepts are individually addressed in the following section. Please remember that this thesis was a secondary data analysis and I had no control over what techniques were implemented in any other portion than that data analysis. Therefore, I am supplying the information to express my awareness of the techniques, but will only address techniques that I was able to implement.

\section{Criteria for Soundness}

Lincoln and Guba (1985) state that, "to demonstrate 'truth value,' the naturalist must show that he or she has represented those multiple constructions adequately, that is, that the reconstructions" are, "credible to the constructors of the original multiple realities" (p. 296, italics in original). Translated, this means that the researcher must 
acknowledge the ontological belief of reality as, "a multiple set of mental constructions" that are made by humans, in their minds, and accessible to those who made them (p. 295). They must believe that the nature of reality is, "multiple, intangible mental constructions, socially and experientially based, local and specific in nature," and, "dependent for their form and content on the individual person or groups holding the constructions" (Guba \& Lincoln, 1994, p. 110). Once that is understood, establishing credibility, or truth value, is a two step process: (1) conduct the research in a manner in which the findings will have a high probability of being credible, and (2) conduct member checks and have the participants approve the findings (Lincoln \& Guba, 1985, p. 296). Credible is the key word in step one of this process. The establish credibility Lincoln and Guba (1985) provide five techniques to assist in establishing credibility, they are: 1) Activities that increase the probability that credible findings will be produced (prolonged engagement, persistent observation, and triangulation); 2) Peer debriefing; 3) Negative case analysis; 4) Referential adequacy; and 5) Member checks (p. 301). Referential adequacy and member checks were two viable techniques for this thesis. However, referential adequacy requires that the researcher, "earmark a portion of the data to be archived-not included in whatever data analysis may be planned-and then recalled when tentative findings have been reached" (p. 313). This option was not implemented for several reasons. One, the data gathered was inherently linked within the focus group environment, thus the exclusion of a portion of the data was more than I was willing to sacrifice. Second, I have included a 
transcript with identifying information removed as an appendix. This addition allows others an opportunity to see the data in its raw form and allows me to keep the data complete. The second possible technique, member check, was not integrated into the data analysis either. This was a function of poor planning and inexperience on my part. To counteract this missing piece is an audit trail which is discussed later under the category of confirmability.

There are three other concepts to consider when establishing trustworthiness; they are transferability, dependability, and confirmability. Transferability and dependability are fundamentally linked and therefore will be discussed together. Lincoln and Guba (1985) state that it is, "not the naturalist's task to provide and index of transferability; it is his or her responsibility to provide the data base that makes transferability judgments possible on the part of potential appliers" (p. 316, italics in original). They further state, "the naturalist cannot specify the external validity of an inquiry; he or she can provide only the thick description necessary to enable someone interested in making a transfer to reach a conclusion about whether transfer can be contemplated as a possibility" (p. 316). Therefore, I have included a 'thick description' of the research site, respondents, provided the original interview guide, schematic of the room where the research took place, as well as a transcript. The inclusion of this information should be adequate for another researcher to examine and determine the transferability of the findings. As stated previously, I do not believe that the findings are generalizable, but that themes found in the data could be tapped into again. 
Regarding dependability, "since there can be no validity without reliability (and thus no credibility without dependability), a demonstration of the former is sufficient to establish the latter" (Guba, 1981).

The final consideration for establishing trustworthiness is confirmability. As specified by Lincoln and Guba (1985) the major technique for establishing confirmability is the audit trail. The six classifications of an audit trail include: 1) raw data; 2) data reduction and analysis products; 3 ) data reconstruction and synthesis products; 4) process notes; 5) materials relating to intentions and dispositions; and 6) instrument development information (p. 319-20). I will address each classification and indicate what file types are available as well as what evidence it supports. Raw data includes electronically recorded materials, field notes, unobtrusive measures, and survey results. I will not be allowing the tape to be heard by an auditor for confidentiality reasons; however, the complete transcript is attached and my notes would be available upon request. There were no measures nor survey results used for this study. The data reduction and analysis classification include field note write-ups, summaries, and theoretical notes; all of which are available in limited terms. Data reconstruction and synthesis include documentation of categories and concepts, explanation of categories and concepts, as well as final reports. All the categories and concepts grew out of the data and are documented in a typology of categories that was created to assist in the conceptualization of the data for the purposes of this thesis. As for the process classification, my access to methodological and trustworthiness notes is 
limited; however, I have included a complete discussion of the trustworthiness issues that apply to this thesis. Additionally, I have made available audit trail notes for anyone who wishes to audit this study. Similarly, I have incorporated intentions and dispositions into this thesis and that information should be sufficient for an auditor. Finally, instrument development notes are not available since I was not a member of the research team at the time of the interview guide creation.

Why focus groups?

As stated by Morgan (1988), "the hallmark of focus groups is the explicit use of the group interaction to produce data and insights that would be less accessible without the interaction found in a group" (p. 12). Similarly, Lofland and Lofland (1995) state, focus groups have:

"the advantage of allowing people more time to reflect and to recall experiences; also, something that one person mentions can spur memories and opinions in others. Moreover, by allowing moments of not having to talk, of being able to listen to others, group interviewing allows each person to rethink and amend any initial account that, upon reflection, seems in need of amplification, qualification, amendment, or contradiction" (p. 21).

Considering this, focus groups were most appropriate for conducting an exploratory study of an evolving community program. Although the moderator had previous experience conducting focus groups on this topic the research team wanted to ensure that the information was emic and not etic. For that reason, the research questions 
were designed to tap into the informants' experiences and opinions; however the range was unknown before entering the research environment. Additionally, the informants were allowed the opportunity to express their opinions and beliefs in a manner that would not have been adequately captured using a survey. The focus group structure also allowed the research team to gather large amounts of data in a short time, generate topics not previously considered, have an interactive environment, and develop a link between the research team and the community.

When considering a qualitative method one must weigh the strengths and weaknesses of the specific method. Morgan (1988) highlights three primary strengths and corresponding weaknesses to consider when using focus groups. One strength of focus groups is, "that they are comparatively easy to conduct;" however, that is not to say that anyone can conduct a focus group properly and moderate a group effectively (p. 20). One drawback linked to the ease of conducting focus groups is that they do not take place in a natural environment. Considering the research agenda, this weakness may make focus groups a non-workable option.

The second primary strength of focus groups is their hypotheses and topic generation feature. This strength was applicable for this study considering the exploratory nature of the groups. However, with hypotheses and topic generation, comes a lack of control of the data that is generated from the group. An ideal situation is to have a trained moderator that can maintain control of the group without stifling topic generation. 
Community Policing Page 19

The third strength and corresponding weakness is the collection of data through group interaction, but beware of group-think. It is possible that the reliance on group interaction is the masking what a respondent would do or say if out of the group environment. However, Considering the above information, focus groups were the best option for the purposes of this project.

\section{Strengths and Limitations}

One strength of this study is the ability to use PPB as a model. Not only has the PPB actively engaged the community in assisting in the evaluation of the program, but recognized that the success of community policing relied on the interaction and contribution that the community is willing to make. Therefore, understanding the model used to implement and develop that relationship is crucial. This thesis focuses in on that relationship and documents the experience of some community members.

Additionally, as stated previously few police departments have used rigorous scientific methodology to evaluate community policing, and none have used focus groups to understand both the criminal justice and the social service provider's experience with the process. This study contributes an important piece in understanding community policing from an academic perspective and fills in some missing pieces in the qualitative evaluation of community policing.

Another strength of this study was the overall research design. The focus groups were convened at two times in the development of community policing. Wave I took place at a time when community policing was being introduced to the community, 
while Wave II data was gathered in a time when community policing was supported by the community and the private sector was involved with providing resources and assistance.

One final strength of this study was its collaborative nature. This grant-based study relied on the expertise of a variety of individuals from three institutions: Portland Police Bureau, University of Oregon, and Portland State University. This collaboration allowed all three institutions to contribute resources and work together towards a common goal.

As with all research, there are some limitations. One possible limitation linked to the methodology was that these groups were intended to be exploratory and were not designed to test a hypothesis; no numerical summaries of the data. The groups were designed to supplement other qualitative and quantitative data collected and provide a broad range of information as well as qualitatively assess change over time. The exploratory nature of the study was intentional and is considered a limitation because the data can only be analyzed within a qualitative framework and depending on paradigm beliefs could be viewed as either a strength or a weakness. Even though, I have indicated the exploratory nature of the study to be a limitation that is not to say that it was a drawback to the study. The exploration of issues and concerns was the goals of the study and this design was well suited for the research agenda.

Another limitation of this study was the sample size. The size of the selected group makes it impossible to generalize. Considering the sample size and qualitative 
method used replication would be unattainable. Nevertheless, the themes discussed in the group could be tapped into again with a group that had similar backgrounds in a developing community policing program. Another issue linked to the sample size was that there was one respondent that had a much closer relationship with the PPB than the other participants in the group; therefore, sometimes dominated the discussion. This will be apparent in later portions of the thesis where the comments are almost exclusively from one person. I have attempted to provide as much supporting information from other respondents; however, sometimes the data did not allow it. That is not to say that the other members were passive participants, but merely that much the data is from that one participant.

Another limitation was the lack of nonverbal communication field notes; this makes it impossible to capture information that enriches the context of the data. However, the data was not compromised by this omission. As recommended previously, I would suggest enlisting the assistance of a qualified non-verbal communication observer if replicating this study.

\section{Personal Expectations and Biases}

This project was my first qualitative research study as well as my introduction into the community policing. As with all researcher, I went into the research arena with both expectations and assumptions. I differentiate between expectation and assumption because to me an expectation is connected to previous knowledge that would make me 
expect people to do or say certain things, or what I wanted to gain out of the experience. On the other hand, an assumption is not based on information previously gathered, but a preconceived idea of what will happen.

My personal expectation for this project was to gain hands-on experience recruiting for and conducting focus groups. I was interested in learning the logistics of conducting these types of interviews as well as how the moderator maintains control of the group without being intrusive. I also wanted experience in managing the large amount of data collected from focus groups. Most importantly, I wanted to learn methods of ensuring the credibility, transferability, dependability, and confirmability of this qualitative method.

I went into the research project with the assumption that community policing was a valuable and interesting style of policing and assumed that others viewed it similar to me. This assumption was based on my previous general knowledge and world view. I was aware that community policing was not an original idea, but was a repackaged policing style from earlier decades. I also assumed that the community was informed of the police activities and philosophy and that social service agencies would be engaged and supportive of the policing style.

Through the course of this research, some previously stated expectations and assumptions were validated and some were diminished. However, I have gained a greater knowledge and understanding of the complex relationships that make 
community policing successful as well as developed a true respect for qualitative research.

\section{Method}

\section{Recruitment Procedures}

Initial contacts with potential participants were made based on the recruitment procedures and contact list from Wave I. The list included the names of those who participated in Wave I as well as individuals who could not participate but had expressed interest in future phases. Included with the list were other agencies to contact for volunteers.

The recruitment process began by contacting those people who participated in Wave I, those who expressed interest the previous year, the agency listing, and consulting the telephone directory's community service section. Once contacted, perspective participants were asked if they were involved with community policing and the level of that involvement to ensure proper placement (e.g., street level or management). If the contact person was not involved with community policing or unavailable the day of the group meeting, a referral was requested. Contacts were told that they would be discussing their involvement and experiences with the PPB's community policing activities as part of a research project that was sponsored by PPB, University of Oregon, and Portland State University. Participants were also informed that they would be audio taped. A confirmation letter was mailed once the person had 
Community Policing Page 24

agreed to participate and reminder telephone calls were made to participants on the day their group met.

\section{Participants and Research Site}

Nine volunteers were scheduled to be in the focus group; however, only four showed up the day of the meeting. The participants included two Caucasian females, one African-American female, and one Caucasian male; the Caucasian male was the only person to have participated in Wave I from this group. All four participants were estimated to be between 35-45 years of age. All the participants were involved with community policing on a management level, but the intensity of that involvement ran the gamut. Organizations represented included a large national social service provider, a local downtown business association, a neighborhood family and youth center, and a city detoxification agency. Since the other four groups in the 1995 series are discussed for context and support, the demographic information is complied in Appendix B.

All the groups were held in a large conference room in downtown Portland and met from 3 - 5 PM on various days in late February and early March of 1995. The conference room had a large table in which everyone sat comfortably, the chairs were large executive style chairs that reclined, and the room had a small sink and refrigerator. The room had two entrances: the main entrance was a glass door that the participants used, and a second solid door that was used for access to the rest rooms and staff lunch room. See Appendix $\mathrm{C}$ for schematic of research location. 
The data was recorded using two portable tape recorders with table top microphones. One was placed at each end of the conference table. All participants were informed before attending that they would be audio taped; consent forms were not obtained.

One important note about this group was that participants had obviously strong external and internal networks with each other. It was immediately clear that the participants were aware of each other within the community and understood how the participating agencies worked together and with the PPB. This was an initial concern, but the transcript shows that they did not try to be politically correct nor hold their tongue in making comments and responding to each other.

About the Data

\section{State of the Data}

For security of the raw data, Dr. David Morgan and I each retained a copy of the audio tape. My tapes, original transcripts, and coding information are stored in a locking file cabinet in a private office. Included is a copy of the transcript with identifying information removed for inspection, see Appendix D.

One note regarding the transcription process was that the groups were not originally designed for transcription; therefore, a speaker's log was not kept. To handle this oversight, a speaker's log was created after the fact. It should also be noted that non-verbal communication notes were not taken during the focus groups. For 
Community Policing Page 26

future research, I recommend that a skilled observer be available to capture non-verbal data and maintain a speaker's log.

To assist in the data analysis a debriefing session took place immediately after each group left the conference room. During this time we recorded our immediate reactions to the group as well as problems or issues that needed to be documented. This debriefing assisted in creating a thumbnail sketch of the groups' comments and issues that needed documented.

The analysis of the data was considered a secondary data analysis even though I was a member of the research team. This decision was made considering that I had no influence over the topics covered in the group, nor spoke to any of the participants during the focus groups. All research team members agreed that my direct involvement in the data collection was clerical and did not influence the data in any way.

\section{Coding of the Data}

Morgan (1988) stated that there are two methods for analyzing focus group data. The first is an ethnographic approach that, "relies more on direct quotation of the group discussions," while the second approach is a content analysis that, "typically produces numerical descriptions of the data" (p.64). Morgan (1988) further states, "in either mode of analysis, it must be recognized that the group is the fundamental unit of analysis" (p. 64). Considering the data available and the recommendation made by Morgan, an ethnographic approach was employed to analyze the data on a group level. The specific analysis techniques relied upon follow. 
Coding of the data was an evolutionary process, not only in terms of what categories matured, but also the analysis procedures used. Lofland and Lofland's (1995) approach and Corbin and Strauss' (1990) grounded theory methods were used to guide the development of categories and understand the data.

As suggested by Corbin and Strauss (1990) 'conceptualizing the data' was the first step in open coding. Open coding is, "the part of the analysis that pertains specifically to the naming and categorizing of phenomena through close examination of the data" (p. 62). During this conceptualization, categories were developed based on the data and the categories thus developed properties and dimensions. These properties and dimensions emerged through a process of reading the transcript, taking notes on examples provided, and focusing on the wording used by the participants ( $p$. 63-72). This process paralleled the recommendations of Corbin and Strauss (1990) when they stated that:

"during open coding the data are broken down into discrete parts, closely examined, compared for similarities and differences, and questions are asked about the phenomena as reflected in the data. Through this process, one's own and others' assumptions about phenomena are questioned or explored, leading to new discoveries" (p.62).

As described above, when a category or property emerges a researcher attaches a conceptual label that is referent to the topic of the category topic (e.g., resource allocation, consistency, partnership and relationships, communication training). This 
grouping of conceptual labels is called categorizing and reduces the number of units that a researcher works with. This process leads to the discovering, naming, and development of categories.

The next step suggested by Corbin and Strauss (1990) is the development of the properties and dimensions within a category. This development process begins by, "dimensionalizing" properties that are characteristics or attributes of a category.

Dimensions refer to where those properties fall on a continuum (e.g., high-low; privatepublic, known-unknown). This process continued on a response by response basis by reading the transcript and noting themes and exploring the properties of the themes addressed by the respondent. Table 3 provides examples of how the categories were developed as well as some of the properties and dimensions.

Lofland and Lofland's (1995) coding method was used in conjunction with Corbin and Strauss' (1990) grounded theory coding methods. Lofland and Lofland (1995) suggest asking questions as the data is shifted and sorted. Questions such as:

- What is this? What does it represent?

- What is this an example of?

- What do I see going on here?

- What kind of events are at issue here? (p. 186) 
Table 3

Partial Typology of Categories

\begin{tabular}{|c|c|c|}
\hline Category & Properties & Dimensional Range \\
\hline Community Involvement & $\begin{array}{l}\text { Personal } \\
\text { Professional } \\
\text { Organizational }\end{array}$ & $\begin{array}{l}\text { High-Low } \\
\text { High-Low } \\
\text { High-Low }\end{array}$ \\
\hline Responsibility Level & $\begin{array}{l}\text { Providing Services } \\
\text { Commitment to Community } \\
\text { Policing }\end{array}$ & $\begin{array}{l}\text { High-Low } \\
\text { High-Low }\end{array}$ \\
\hline Interaction with Community & $\begin{array}{l}\text { Consistency } \\
\text { Accessibility } \\
\text { Satisfaction }\end{array}$ & $\begin{array}{l}\text { High-Low } \\
\text { High-Low } \\
\text { High-Low }\end{array}$ \\
\hline Consistency & $\begin{array}{l}\text { Allocation of Resources } \\
\text { Training } \\
\text { Personnel } \\
\text { Across Precincts } \\
\text { Across Counties } \\
\text { History }\end{array}$ & $\begin{array}{l}\text { Equal-Unequal } \\
\text { Complete-Incomplete } \\
\text { Consistent-Inconsistent } \\
\text { Consistent-Inconsistent } \\
\text { Consistent-Inconsistent } \\
\text { Briefed-Abandoned }\end{array}$ \\
\hline $\begin{array}{l}\text { Informed about Community } \\
\text { Policing }\end{array}$ & $\begin{array}{l}\text { Assumptions } \\
\text { Definitions } \\
\text { Community Contacts } \\
\text { Bureau's Goals }\end{array}$ & $\begin{array}{l}\text { Understood-Vague } \\
\text { Clear-Unclear } \\
\text { None-Many } \\
\text { Private-Public }\end{array}$ \\
\hline Results/Responses & $\begin{array}{l}\text { Effectiveness of Response } \\
\text { Crime Level }\end{array}$ & $\begin{array}{l}\text { Quick-Slow } \\
\text { Increasing-Decreasing }\end{array}$ \\
\hline
\end{tabular}

During the process of reading the transcript I asked myself these types of questions. The recording of my response was a word or small set of words that evolved into my codes. Examples of codes included level of community involvement, consistency, responsibility level, informed about community policing, and resource allocation. Also indicated on the transcript were those words and phrases that I wanted 
Community Policing Page 30

to ensure were captured, including interesting quotes and properties of categories that needed to be noted.

\section{Results and Discussion}

The collected data developed into six major categories: 1) personnel policies and institutional memory; 2) training; 3) consistency; 4) community involvement and responsibility; 5) partnerships or relationships, and 6) change over time. These categories are neither mutually exclusive, nor mutually exhaustive but capture the primary issues.

The implementation and sustenance of community policing relies on a network of agencies and individuals working together in a cohesive fashion, not in isolated pockets. This cooperative nature spilled over into the categories made it necessary to make decisions regarding presentation of the data based on goodness-of-fit as well as the subjective opinion. Following is a discussion of each category followed by a general summary and suggestions for future research.

\section{Personnel Policies and Institutional Memory}

An issue that needs addressed by the PPB is how to blend the quasi-military police structure of the department with the philosophy of community policing. A participant summarized the issue by saying, "if there is one Achilles heel right now with community policing it's the institutional way the Bureau moves personnel... it's antithetical to community policing if community policing is relationships, and I really think relationships are more important than institutional partnerships" (R2). Personnel 
issues such as turnover, promotion, disciplinary removals, and the like are embedded in the quasi-militaristic style of governance. Directly linked to these personnel issues is institutional memory. This emic term refers to officers knowing what relationships, partnerships, problems, and resolutions have occurred over the years--essentially a history. Respondents' statements concerning institutional memory were linked to the Bureau's personnel policies; therefore, that link will be maintained and discussed as one category.

Following is a community members' perception of what happens when a promotion occurs:

'A guy is promoted and there are two vacancies; one is in the neighborhood he has been working and the other is in a neighborhood across the city. The Police Bureau's institutional bias is to move the person out of the neighborhood he has been in and to the new one. Taking that person who has expertise in the neighborhood as an officer and they become a sergeant and are transferred to North Precinct where they know nothing about gangs, they know nothing about St. John's, they know nothing about whatever. But the Police Bureau believes that you move people so that they do not become entrenched in the neighborhood and become corrupt and then extort money. It is the way policing is. It's not just Portland--this is in reaction to the Tammy Hall type stuff that happened in New York in the twenties where every neighborhood cop was extorting money from neighborhood merchants and they break those 
Community Policing Page 32

relationships by moving people around constantly so they cannot get themselves entrenched. Well, the Portland Police are still doing that kind of stuff even though they are saying they want to do community policing. And it's extremely disruptive to the community when you are trying to solve a problem'(R2).

In this example, the promotion is good for the individual officer; however, the community has lost the relationship built with that officer and must begin anew when a replacement officer is assigned. Another example of how the personnel structure had a negative impact on the community was provided by a program supervisor of a neighborhood family and youth center. This example refers to a city annexation that altered which criminal justice agency was responsible for the neighborhood and removed two officers that were very active in the center. Refer to Appendix E for schematic and details on the services provided by the neighborhood center.

'There were two officers, Officer $\mathrm{X}$ and Officer $\mathrm{Y}$, and everybody knew $\mathrm{X}$ and $\mathrm{Y}$ and so it was a very positive experience for the community because these officers could walk into the school and everybody didn't head out or turn their heads. They [the youth] just had a lot of experience with the police that was not strictly criminal activity. These were men who were involved in the community in other ways and so people would come up and ask them for extraneous things and they could make it happen. They also used bicycles a lot to patrol around the areas and talk with people and be out and available so that relationship really grew and it was very strong. Then they shifted and decided 
to not do it that way and it then started with a county and a city person and then it went away. The county officers were transferred to the city about a year ago and they're choosing not to operate it that way anymore. So, what started out as an extremely wonderful thing is starting to sort of deteriorate and go back to the old way and it is something that my agency is quite distressed about' (R3).

This example reflects how the police structure and politics of policing directly affected individuals within the community and had a negative effect. As this and the following examples illustrate, the police structure, personnel policies, and community policing philosophy are at odds with each other and are a source of frustration for the community. One specific example of how personnel changes have effected the community include the inability to develop a trusting relationship with an officer, particularly with the youth population. R3 eloquently stated the problem by saying: 'There are a lot of youth everywhere in this city that have no reason to trust adults because adults have hurt them in some way in the past and we don't exist in a society today where you can go to a police officer-they are always your friend-or you can always go to a teacher or always go to a counselor... People were going to these officers [Referring to Officer $\mathrm{X}$ and Officer $\mathrm{Y}$ ] because they had taken the time and built that relationship, and built that trust. So that maybe they could look at this as an adult that they could bounce an idea off, and they would see them all the time in the community. So, I think it is a really 
important thing and I think with all the movement of the Police Bureau there is no way to build that. People, adults and kids, are just supposed to trust a police officer, but the reality is that there are just too many examples of times, not just police officers, but any adult or system has been more abusive than helpful' (R3).

The following quotes capture more of the frustration found within the community regarding this issue:

"Moving the people [referring to officers] around all the time makes it really hard because next week you may have somebody different who you can't necessarily communicate with" (R1).

"Transfers are driven by union contracts, seniority, and job availability. That says nothing about whether or not a person is matched to a neighborhood, matched to an assignment, matched to a set of problems. It is how long you have been where you are, where the next opportunity is, where you are on the list, the hire list or promotion list"(R2).

As stated previously, respondents indicated understanding that institutional memory was a function of the personnel policies. However, the concern remained over the lack of institutional memory. The informant most closely involved with community policing provided the majority of the illustrations of this point, but the other participants did assert agreement with the following statements. 
Community Policing Page 35

"There is no system in the Bureau for transferring the knowledge from the guy going out to the guy coming in. If the guy going out cares enough to sit down with the guy coming in, and it might be a woman, you know, and educate them, then that neighborhood has really benefited in a way that is not the norm"(R2).

"It's very difficult to have a project in place and say this is what we have been doing and have the new person come along and not have dittily interest in continuing the status quo. Even if you think the status quo is very successful" (R2).

Again, the respondent most closely affiliated with the PPB expressed these words related to turnover and institutional memory.

'I honesty see myself as the person that trains the new precinct commander. They come into their position and I call them up and say, "Let's go have lunch." Then I try to meet with them as often as I can in the beginning, explaining to them all the things that their people have been doing in hopes that they will not come in and turn the apple cart totally upside down and tell everybody to do something different because that happened the first couple of times' (R2). In sum, "You have to explain the entire story to them again" (R3). Considering the level of frustration expressed, it was clear that this issue needs addressed in order for the community to feel that their efforts are appreciated and that community policing includes both the community and the police. However, the need for this type of 
tracking system would not be needed if the policy for promoting officers was altered so that officers could stay in the neighborhoods where they have developed their relationships. All agree, this is not an issue that will be resolved easily nor quickly considering the tradition of following a military model for promotion and transfers are deeply ingrained in the police community

\section{Training}

For purposes of this thesis training encompassed a variety of properties ranging from general police training, to human service training, to community interaction, to learning how to work with outside agencies.

One segment addressed the PPB's resistance to developing programs and working relationships with social service agencies. One respondent summed up the issue by saying, "The tendency with the Bureau has been to set up programs in response to community needs internally versus putting those resources into existing systems" (R4). This particular respondent assisted in the development of the internal information and referral guidelines and indicated that officers on the committee were saying, "We're not social workers, and we don't want to be social workers" (R4). This resistance to incorporating outside resources into the policing model was one that varied for each informant, but was an important piece to consider when developing relationships between agencies and the PPB. The attitude of us versus them needs to be replaced with an attitude of collective effort towards a mutual goal. 
Another important issue that surfaced was that the community felt responsibility to train officers in the field. This was a heated issue and may be an issue the community is beginning to feel resentful about.

'Every time we meet up with a police officer that we don't know who has somebody [a citizen under arrest or detained] waiting for us, we train them. Right there in the street. This is what we do, this is what we don't do. This is what we expect from you and this is what you can expect from us' (R1).

"I think the training piece is key to community policing. The problem is that I think that we spend a lot of energy doing just that. That training that should be spent in other places. I'm not sure there shouldn't be a better way. It shouldn't burden the human services part which is already overburdened" (R4).

Simply said, "We train them. We train the recruits" (R1). The previous statements provide evidence that the group felt that most of the human service training became their responsibility through on-the-job contact or by being invited to teach at Special Academy, a police training program.

Another major issue related to training was the lack of communication training. This was a powerful segment relating to police. $R 1$ stated that officers needed to be trained to communicate with substance abuses, battered women, mentally ill, and the youth population, to mention a few. The point of communication training and the mentally ill brought forth very strong words and something all respondents indicated 
being concerned about. The strength of that conviction was expressed when R2 said, "a couple of people have engaged in police assisted suicide, or whatever you want to call it." This statement referred to incidents in 1995 with the mentally ill where the lack of ability to communicate with these citizens had deadly consequences. In response to this discussion, it was stated that the PPB had taken steps to find solutions to the communication issue by exploring a model in Memphis, Tennessee. R4 responded. "They are going to potentially open that up to officers that are interested in becoming good communicators so they don't have to shoot people anymore. And that is the key, that's the key to targeting those people that really have an interest or a skill in dealing with substance abusers or whatever and utilizing their skills instead of looking across the system to teach everybody" (R4). Concerning other training issues respondents had the following to say. 'I think that the key is ongoing training. You can only gleam so much information from the classroom.' R3 further stated, 'and so it is doing it both ways and learning to blend that together and not just assuming that the education, the formal education stops once they hit the streets' (R3).

“... the interaction I have with officers who after the second time the woman has gone back, the officer has written them off because they don't understand what the norm is in the domestic violence situation" (R4). 
Of all the training issues, communication training surfaced as the most important. Being able to talk with all of Portland's citizens was a significant factor and was a point that the social service providers expressed concern about. While they recognized and appreciated that Portland presents the PPB with a massive amount of variance, they asserted that the ability to work with all citizens is a major key to the success of community policing. Additionally, increased communication training should assist in incorporating populations that have been overlooked such as the youth population and Asian immigrants.

\section{Consistency}

Consistency was an issue across all categories. Depending on the data analysis adopted, consistency could have been viewed as an individual category, or as a property of each category. I maintained it as a category in and of itself even though issues of consistently arise within all other categories. Additionally, this section encompasses both consistency and inconsistency issues

Consistency appeared to be the key to the success or failure of community policing in the eyes of the social service providers. Comments indicated a very good working relationship with specific officers as well as police divisions; however, across the board, respondents felt that behavior indicative of community policing vary according to individual officers. 
"I find it inconsistent from officer to officer. I mean, I know street officers. They all have a little different idea of what it means and when they're doin' it and when they're not doin' it"(R1).

When consistency was discussed, it took on many different meanings. Some properties of consistency referred to the allocation of resources, training, level of commitment to community policing, personnel assignments and promotions, as well as consistency across and within the five precincts. Even though community policing is officially practiced within the Bureau, there is no definition that all precincts and officers accept. To increase consistency, the Bureau needs to define expectations of officers and community agencies.

As much as respondents indicated a desire for consistency in community policing, they also acknowledged that each neighborhood presented the PPB with a different set of issues that may not be solved in the same manner, and to a certain degree, needed inconsistency for effectiveness. One example provided related to police treatment of substance abusers, while another addressed individual commitment levels:

"Well, I don't see any. We don't see a whole lot of it-consistency. I mean between individuals all the police are very different. The majority of them are great, kind, caring people. The inconsistency would come in with those who have a problem with drunks. And there are those who have problems with the drunks for one reason or another. That's where I see the inconsistency. It has to be on an individual level. For me, it can't be on an agency level. (R1)" 
"I think for me the piece I see as most inconsistent is the level of commitment and that is from an individual officer level. I think the commitment is there up high, but as you trickle down the level of commitment at different places lessens and I don't know if it's feasible to make everybody equally committed to it" (R3).

In a similar line, $\mathrm{R} 2$ expressed a clear understanding of the difficulty the PPB has with developing consistency across precincts by saying, "You've got five precincts with five commanders with five command structures and each of these people have a personality, and management style.... and the environment that they are doing community policing varies" (R2). R2 continues to defend the PPB by stating, "It's really hard to talk about community policing as a monolith because the Bureau isn't and I think you need to recognize that" (R2). In support, $R 3$ stated, "There are parts of it that I don't think need to be consistent because they need to be responding to what each of the communities think."

The above statements illustrate the broad range of consistency issues that arose out of the discussion: (1) individual officer training; (2) police structure and, (3) commitment levels.

Since this group was relatively small, it cannot assumed that this is representative of all social service agencies experience with community policing. However, the discussion was broad enough and the experiences varied enough to have 
confidence in presenting them and not being too concerned with the possibility that the results are idiosyncratic of the four participants. It was also clear that community leaders, although they desire consistency, recognize that not all the neighborhoods need the same type of attention from the police department. They recognize that some neighborhoods need officers with special training to deal with young people, some need to be able to work in the suburbs and deal with car prowlers and burglaries, and still others need to be concerned with squatters and homeless camps.

In sum, these social service providers expressed a desire for the PPB to understand the special needs of each neighborhood, and have officers trained to deal with the situations that are of concern to that area. At the same time, recognizing that the needs of the neighborhoods vary, they believed that there still needed to be a consistent level of commitment to community policing.

\section{Community Involvement and Responsibility}

This category is a paradox. On one hand the community was willing to accept their role, while on the other hand some community members were resistant, believing that policing is the sole responsibility of the Bureau. This contradiction complicated that discussion of this category, but is a valuable quandary to consider.

The following quote described how one agency willingly adopted responsibilities typically associated with a police department:

"We are actually providing what we would call quasi-police services to the public areas in downtown. The guides and the patrol officers that support them 
are paid for by us and out there at our direction if you will and we have seen that as certainly an aspect of community policing for a private business organization to take on some of the functions of the police bureau" (R2).

This program is unique in that it is, "able to marshal a significant amount of resources privately so our organization has more of a partnership with the police bureau in an operational sense almost" (R2). The respondent also indicated that, "there are folks out there that call our people the (agency name) police.' Obviously, this agency has the financial ability to contribute significantly which is not the norm. Additionally, the previous example of community responsibility was an external addition to the police department. Most other agencies indicated an internal involvement with the PPB. One participant indicated participating in the development of the information and referral sub-system within the department.

'I sat on the committee that helped design the in-house $I$ and $R$ piece and continue to work very closely with the staff that do the information and referral for the officers, and the creation of data, and how that is disseminated' (R4). However, this respondent also indicated that her agency has experienced resistance from the PPB regarding giving up ownership of some traditional police responsibilities. As support, the respondent stated, 'My sense is also a real resistance to wanting to set up internally versus accessing external sort of things that are already in place' (R4). The respondent provided the example of the creation of the Domestic Violence Unit as additional support when she stated: 
'I think the Domestic Violence Unit is very good, but there were things in the community that could have taken those resources and utilized them and done the same things for them. So, I think there has been a real struggle with them to want to do it themselves versus looking outside' (R4).

As stated previously, resistance to developing a working relationship was seen from both sides. "I think some people have looked into what role they can play and others still want the police to take the first 500 steps and then maybe" (R3). This was further represented when, $\mathbf{R} 3$ stated:

'Everybody wants the police to take care of things, and the courts to take care of things. That's a lot of what drew up ballot Measure 11. People don't want to get involved, they just want it taken care of. I think that the part of community policing-good community policing-is community and getting that community to be accountable and take some of the responsibility in that. A lot of times the community and the homeowners and the business people have a lot of expertise that goes untapped, as does the Police Bureau' (R3).

Similarly, while respondents indicated wanting the PPB to utilize existing external services the social service agencies were also saying, "We don't want anything to do with this as a social service agency, because we can't handle anymore. We already got more than we can handle. We don't want officers handing us another 200 people" (R4). This was expressed differently by R3 and related to citizen responsibility, "I think sometimes neighborhood associations can fall stagnant because neighbors don't 
get involved and so you get the same dozen people that are coming" (R3). This lack of citizen involvement linked back to the issue of personnel shifting when R3 stated:

'I think people don't know who their contact person is. I know there exists a contact office, but I don't know where it is... and what I understand from people is that should they try to go there, there is usually not even an officer there' (R3).

The issue of community commitment was illustrated by a graffiti removal project. "I was talking with the man who was coordinating it about a year and a half ago and they did a phenomenal amount of work because you have to. If it's on a business, you have to have the business owner's permission to paint on the building and paint over the graffiti and a lot of the owners are absentee owners are in other states. So you are actually calling California to say, 'Hi. You have graffiti on the side of your building. Do you mind if we paint over it?' And getting no response or some people will respond, 'Absolutely, go right ahead.' Other are like, I don't care. If you want to. Or absolutely not, I don't want you on my property" (R3).

The oxymoronic nature of the community was again captured when R4 stated:

"I was just sitting here listening to people and thinking we've probably, as a community, made them fairly schizophrenic too because I can see that there has probably been a lot of pulls in a lot of different areas and not necessarily a process internally to decide where to pick which one of these because 
everybody, if you talk to anybody, every neighborhood has something they want from community policing...I think in social services we've not always been real responsive when we've gotten that call from an officer that say, 'This is what I've got.' And our response is tough. And you truly get one chance with an officer" (R4).

For community policing to flourish both the community and the police must work together. Although not all organizations have the same amount of resources to dedicate, the concept was the same--get involved and get the precincts to pay attention to what you want.

"I think the community needs to take some responsibility for the community...It really does mean that people have to get out and get involved, and if we are not going to be involved it is unlikely that the police are going to see much reason to be involved" (R4).

"I think people are finally waking up and realizing that if we don't get involved with the police that it's just not going to happen. I think we have gotten past the blaming of the police department stage and people are starting to stand up and reclaim their neighborhoods" (R1). 
'I think there are a lot of times that when the police become the bastard stepchild and can't do anything right and people are just pounding on the police. Part of a partnership is the community" (R3).

Previous statements indicate that the community is in a situation where sometimes it is willing to give of itself and actively participate in community policing while other times, it wants to police to be solely responsible. While the community criticized the PPB for being inconsistent in its level of commitment, the same can be said of the community. As with all developing programs, the parts must work together and determine what is the best fit, who is most effective in what situation, what can each agency bear, and the like. That process is currently going on within the community. The community is trying to find out how it best fits within the policing system without sacrificing what they are already doing within the community.

\section{Partnerships and Relationships}

Another important category for the respondents was the use of partnerships and relationships. It was interesting to see how the informants denoted the differences between the two and how vital they were for continuing community policing and dealing with dwindling financial resources.

One respondent from a local alcohol outreach program whose job it is to pick up inebriates off the streets indicated, "We've had our numbers drop dramatically. Our statistics tell us something is working" (R1). This 'drop in numbers' was encouraging 
to the respondent and was followed up with the recognition of other agencies that they network with:

'I don't know if it's the [program name] outreach program or whether it's the combination of community policing and the [program name] and [downtown business organization] and [private security company name], but probably all those things come into play. So, we are a big supporter of community policing, especially in the Old Town area. When the bicycle police were out, they would do a drug bust in nothing flat. That was part of the program. They help us with our particular clients and we certainly help them. They call us all the time. I think it is a good program' (R1).

Similarly, when R2 was discussing partnerships many other agencies were incorporated into the response. This fact made it clear that agencies were networking to solve problems and to assist the police. In R2's words:

'If you look at the central business district you've got [program name], [mental outreach program name], [downtown business organization] folks and the PPB all working on what I would call order maintenance issues in the central core. Downtown is sort of the crossroads of the city. It is a collecting point for all kinds of people: rich, poor, honest, dishonest, homeless, housed, chronically mentally ill, healthy, and substance abusers. Managing that environment is something that I think from our perspective the police have certainly opened their arms to these other non-profit entities to help them manage.... So I say 
Community Policing Page 49

that there is a very close working partnership both on the street and the operational level in terms of the street officers communicating with our people' (R2).

'Partnership in the community is one of the strengths of what community policing is supposed to be about. It is sort of just from a financial dwindling resources perspective that people are being forced to look at partnering with other agencies and other organizations in ways they never really been forced to do before' (R3).

The act of writing a formal partnership agreement was not as important as having a solid working relationship with different agencies. The existence of a document that pronounces their willingness to work together does not make that affiliation effective "I guess there is a formal partnership agency to agency, but more of a relationship then a formal partnership. I think the formal partnership is understood. It just exists, and then what we do is really down to the reality. You know, person to person, interpersonal kind of things: solving problems and dealing with situations" (R1).

These selections demonstrate how valuable from a financial perspective as well as from a community policing and communication perspective these types of interactions are. These types of interactions should strengthen the community policing model and enable more people to get involved with the experiment. The 
implementation of formal or informal partnerships and relationships was seen by one respondent as, "the whole essence of community policing" (R3). However, the respondent also indicated an awareness of how difficult it is to assess partnerships and relationships by saying, "when you get that many people involved, there is no way to isolate any one factor" (R3).

\section{Change over Time}

This portion of the results and discussion section was included to provide support for the efforts of the PPB and community policing. The purpose was to illustrate the respondent's perspective that community policing has developed and changed for the better. For that purpose, I have chosen to include quotes and let them speak for themselves as a summary.

'In the beginning it was pretty hit and miss and now it's pretty consistent. So, I think it is working in a way that when I started doing this stuff I didn't think it ever would' (R2).

'From my own experiences, there has been a tremendous amount of incremental change in how the Bureau is doing business. As I have gotten to know the Bureau and understand the culture and to realize how far they have to go. I give them a lot of credit for having been able to go as far as they have gone in five years' (R2). 
'I think as far as the business district goes over there, the merchants going to the police and in response the police have started coming to their community meetings, their business meetings, and neighborhood meetings. I think that most of the neighborhood association meetings have some kind of police representative at their meetings' (R1).

"I think that the Police Bureau is doing a terrific job in trying to institutionalize community policing. It is not all there yet, it's not perfect. But you are going from a quasi-military organization five years ago, where it was all top down, and nobody on the front lines thought, they just followed orders, to an institution that has really gone a long way to change those norms and morays" (R2).

"I don't think it could be the institution it was five years ago now. I really think that it's so institutionalized at this point that if a new police chief were to come in tomorrow and say, "Forget this community policing we are going to go back to the standard stuff." I don't think they could do it. I don't think that the rank and file would follow" (R2).

"So, the Police Bureau did a lot of outreach and a lot of coordination in trying to meet that," [referring to goals of neighborhood associations] (R3). 
Community Policing Page 52

"We've had an excellent relationship with them since they came into being a few years ago. We've had our numbers drop dramatically. Our statistics tell us something is working" (R1).

\section{General Discussion and Future Research}

Community policing is a huge system of partnerships, relationships, private and public resources, personnel decisions, political decisions, different parts connected and relying on each other. This thumbnail perspective into the intricacies of the system illustrates that it is far from perfect. Nevertheless, both community leaders and the police recognized that in order for community policing to work it must be the community and the police. Each cannot stand on its own, each must recognize the efforts of the other and accept the financial as well as personal commitments of the other. All included in the process need to feel that the return on the investment is worth the effort. I suggest that the Bureau and community seek out and continue to develop relationships and actively work toward a common goal.

The most highly discussed issue was the discrepancy between the philosophy of the Bureau, community policing, and the way in which they move personnel. There was also a great deal of concern regarding the level of involvement that the community had in making real decisions and being appreciated within the community policing structure. 
Community Policing Page 53

Everyone who participated realized that community policing is a complex system of relationships, partnerships, private and public funding, commitments to common goals and support of the greater community and without any of these parts the system cannot function as a whole. This was illustrated with the experience provided by R3 (referring to Officer $\mathrm{X}$ and Officer $\mathrm{Y}$ ) and how one political decision changed a very positive and meaningful relationship for many people within the. Additionally, as a respondent stated, "I think the community knows what power they have, and if they were to access it and organize it and tap into it a lot more could happen, but I think it is sort of general ignorance" (R3).

One segment of the discussion not discussed in detail related to the politics of policing. The social service providers clearly understood how to work the political structure to get what they wanted. The most striking statement came from R2 referring to what steps could be taken to re-institute a project that was disbanded due to a change in personnel. "Well, you can jump over the commander's head and go to the Deputy Chief and say, 'Deputy, Chief, this commander doesn't like our neighborhood project and we like it. Why don't you tell this commander that they need to value our community policing project?' You always use those words--community policing project" (R2).

One interesting note relates to the fact that only one respondent indicated a personal involvement with a neighborhood association that was not part of their professional requirements. It may have been the wording of the question, or that 
people really did not think their non-work related experiences were part of the inquiry. It would have been ideal to explore that area and see if those individuals who are high level professionals with interaction carry that involvement into their neighborhood associations and block watches.

Another very important issue addressed by the criminal justice management level and social service street level groups were that officers who did not want to participate in community policing are self-selecting themselves to work the graveyard shift. This appears to be done to avoid working the shifts in which an officer's noncommitment to community policing would be more noticeable. If this trend continues, there will be a distinct split in the department and will cause severe consistency issues. The social service street level group indicated seeing the beginnings of this split when they are working with officers from that shift, especially when dealing with situations where children needed to be removed from a house.

Additionally, the research team found that the youth advocate group had a much more limited experience and direct knowledge of community policing. That focus group was more of an information sharing group that a group discussion. Many of the participants were unaware that there was a specific officer assigned to their facility or neighborhood. Additionally, these respondents indicated, as previously mentioned, that the night shift officers have a difficult time communicating with the youth population. Likewise, officer turnover and youth training were strong issues of concern. 
Another issue related to community involvement arose within the street level criminal justice agency group. It was linked with a discussion of how to assess community policing when the group indicated that the use of statistics was not desirable, but also indicated frustration with anecdotal evidence. The participants did not view the media as an alternative to spreading the word about community policing because they felt there was a hidden agenda when working with the media.

Data analysis suggests that the level of confidence and support felt by social service providers has increased dramatically, which is supported by comments included in the change over time section of this thesis. Although, the group participants still have many issues they would like to see resolved, all recognize this is a process that takes time. Generally, community policing has rooted itself and established a footing with the social service providers who are committed to assisting in the molding and development of community policing as well as providing resources to assist in that journey.

Future research projects on this topic are plentiful. First, there are four more tapes from the 1995 series that need to be analyzed. Those in combination with the data from this group would easily produce at least a dissertation. Similarly, the influence of $R 2$ on this specific group could be investigated. That line of investigation would be very interesting given R2's role within the social service structure as well as the detailed knowledge of the PPB. Another project could use the focus group data from 1994 and compare that with the data from 1995, also producing at least a 
Community Policing Page 56

dissertation. If a researcher wanted to collect new data, the research design adopted here could be extended for a Wave III. All of the above research ideas would provide a researcher with valuable experience as well as be of value to the Portland Police Bureau. 


\section{References}

Austin, D., \& Sweet. C. (1992). Information and referral efforts extend departments reach. The Police Chief, (December), 65-66.

Guba, E. G. (1981). Criteria for assessing the trustworthiness of naturalistic inquiries. Educational Communication and Technology: ED\&TJ, 29(2), 75-91.

Guba, E. G., \& Lincoln, Y. S. (1994). Competing paradigms in qualitative research. In Norman K. Denzin \& Yvonna S. Lincoln's (Eds.). Handbook of Qualitative Research. (pp. 105-117). Newbury Park, CA: Sage.

Leighton, B. (1991). Visions of community policing: Rhetoric and reality in Canada. Canadian Journal of Criminology, July-October, 485-522.

Lincoln, Y. S., \& Guba, E. G. (1985). Naturalistic Inquiry. Newbury Park, CA: Sage.

Lofland, J. \& Lofland, L. H. (1995). Analyzing Social Settings A Guide to Qualitative Observation and Analysis. Belmont: Wadsworth Publishing.

Lurigio, A. J. \& Rosenbaum, D. P. (1994). Crime and Delinquency [Special Issue: Community Policing]. Thousand Oaks: Sage.

Marshall, C. \& Rossman, G. (1995). Designing Qualitative Research. Thousand Oaks: Sage.

Metro-Dade Police Department. (1995). Annual Evaluation of Community Policing. Crime Prevention and Juvenile Programs. Miami, FL. 
Montgomery County Police, Community Policing Project. (1990). An Overview of Community Policing. Montgomery County, MD

Morgan, D. (1988). Focus groups as qualitative research. (Sage University Paper Series on Qualitative Research Methods, Vol. 16). Beverly Hills: CA.

Oettmeier, T. N., \& Brown, L. P. (1988). Developing a neighborhood-oriented policing style. In J. R. Greene and S. D. Mastrofski (Eds.). Community policing: Rhetoric or reality? (pp. 121-152). New York: Praeger.

Palmiotto, M. J. (1996). Influence of community in community policing in the twenty-first century. In R. Muraskin \& R. Roberts (Eds.), From Visions for Change: Crime and Justice in the Twenty-First Century (pp. 116-127). Upper Saddle River, NJ: Prentice-Hall.

Patton, M. (1987). How to use qualitative methods in evaluation. Newbury Park, CA: Sage.

Portland Police Bureau. (1995, October.) Community Policing Performance Measures Final Report and Appendix.

Pratt, C. E. (1995). Police Officer's Guide: The Definitive "How To" Handbook of Community Based Police. San Antonio, TX: Police Management Consultants.

Strauss, A. J. \& Corbin. (1990). Basics of Qualitative Research: Grounded Theory, Procedures and Techniques. Newbury Park, CA: Sage. 
Community Policing Page 59

Teasley, D. (1994). Community Policing: An Overview. (From National

Institute of Justice Community Policing Topical Bibliography, Document No. 136)

Trojanowicz, R. \& Bucqueroux, B. (1990). Community Policing: A

Contemporary Perspective. Cincinnati: Anderson Publishing

Trojanowicz, R. \& Pollard, B. (1986). Community Policing: The Line Officer's Perspective. East Lansing, MI: National Neighborhood Foot Patrol Center, School of Criminal Justice, Michigan State University.

US Department of Justice. (1995). Community Policing and D.A.R.E.: A

Practitioner's Perspective. Washington, DC: Bureau of Justice Assistance.

US Department of Justice. (1994, August). Neighborhood-Oriented Policing in Rural Communities. A Program Planning Guide (Monograph). Washington, DC: Bureau of Justice Assistance Response Center.

Vaughn, J. (1991). Community-oriented policing: You can make it happen. (Available from Planning and Support Division, Portland Police Bureau, 1111 SW 2nd Avenue, Portland, OR 97204)

Williams, E. (1995). Implementing Community Policing: A Documentation and Assessment of Organizational Change. Unpublished doctoral dissertation, Portland State University, Portland, Oregon. 


\section{Appendix A. Interview Guide.}

Thank you for coming to talk with us about community policing today. Each of you have been mentioned as someone in your organization who would know about the operation of community policing, particularly in terms of the ways that it connects with the things that groups does. The main topics that interest us are:

- Finding ways to assess the performance of community policing, and

- Finding ways to improve that performance

In community policing, how well the police department works with other organizations and agencies is one important aspect of assessing the performance of the community policing program. That is where you come in.

So, we want you to think about, from your organization's point of view:

- How well is community policing doing?

- How can that level of performance be improved?

These are the questions that are being asked about community policing, not just in Portland, but around the country. That grant that we have uses the Portland experience as a model to being providing some answers.

Before we begin, do you have any questions for us?

Icebreaker: Let's start by going around the table and each of you can say who you are and what group you're with.

1. (15 minutes). From your point of view and your organization's, how well informed do you think your organization is about the Portland Police Bureau's community policing activities?

- Have the police made any specific efforts to inform you about community policing?

- Do you think that you need to be informed in more detail?

2. (10 minutes). On what occasions do you or the people you work with meet with police personnel, either oneon-one or in larger groups, to discuss specific issues and projects in the community?

- Are these productive meetings?

- Do you feel like you are dealing with each other on an equal basis?

- Are there some ways that community policing makes it easier for your organization to do some things that you would like to do?

- Are there some ways that community policing makes it harder for your organization to do some things that you would like to do?

3. (5 minutes). Does your organization have any written cooperative agreements with the Portland Police Bureau, either in general or in some limited part of the city?

- What are some of the topics of these agreements-what kinds of problems do they address?

- How do they usually get initiated?

- How well are they working?

4. (10 minutes). Have you or your organization seen any specific advantages from closer relations between your organization and the Police Bureau?

- Have you seen any changes, either good or bad, in the quality of services that you can deliver to your clients, since community policing began?

- Are there any changes, either good or bad, in the way you or your co-workers do your job, since community policing began?

- What about referrals to your agency, have those changed at all?

- What about some advantages that might show up down the line, but that haven't happened yet-do you see any positive developments in the future? 


\section{Community Policing Page 61}

5. ( 10 minutes). If I asked you, "What is the biggest way that community policing has affected your agency?" What would you say?

- How much does it affect the way you operate in the community?

- How much does it affect your dealings with clients?

- Your contacts with other groups or areas in town?

- What else does it affect?

6. (20 minutes). From your point of view and your organization's, thinking about the parts of the community that you work with, there are undoubtedly some parts where problems with social disorder have improved over the past couple of years, and some parts where it has gotten worse.

- Where are things getting better?

- Where are things getting worse?

- Thinking specifically about the amount of crime, where has that changed? What about fear of crime? Where has that gone changed?

- What about the physical quality of the neighborhoods?

- Does community policing get any credit (blame) for any of this?

7. Can you give me some examples of situations where the police have been involved in cooperatively identifying community problems?

- What about helping to resolve problems that have been identified, can you give me an example of where the police have been involved in resolving problems?

8. Tell me whether you agree or disagree with this statement: "People of all sorts are supporting community policing in Portland."

9. Here are some terms that might describe community policing, give me your reactions to them

- Open?

- Democratic?

- Well-defined?

10. Training is an important issue that arises when there is a shift to community policing. Are you aware of any changes in the police's training that affect how they deal with you or your organization?

11. Many of your agencies and even some of you talked to us a year ago, so we're especially curious to hear how you feel community policing in Portland has changed over the past year or so. If you were to point to one or two things about community policing that have changed, what would that be?

- Suppose we came back a year from now, what might have changed by then?

- Suppose we had Chief Charles Moose [current PPB chief] and Vera Katz [current Portland mayor] right here, what one piece of advice would you give them about community policing?

Is there anything else you would like to tell us? 


\section{Appendix B. Focus Group Participant Information.}

Social Service Management Level Participants

\begin{tabular}{l|l|l}
\hline City Detoxification Agency & African-American Female & \\
\hline Downtown Business Organization & Caucasian Male & Wave I \\
\hline National Non-Profit Organization & Caucasian Female & \\
\hline Neighborhood Organization & Caucasian Female & \\
\hline
\end{tabular}

Criminal Justice Management Level Participants

\begin{tabular}{l|l|l}
\hline County Sheriff's Office & Caucasian Male & Wave I \\
\hline Downtown Homeless Shelter & Caucasian Male & \\
\hline Portland Police Bureau & Caucasian Male & \\
\hline Private Security Company & Caucasian Male & Wave I \\
\hline School Police & Caucasian Male & Wave I \\
\hline University Security & Caucasian Male & \\
\hline
\end{tabular}

Social Service Street Level Participants

\begin{tabular}{l|l|l}
\hline Anti-Drug Coalition & Caucasian Female & Wave I \\
\hline City Detoxification Agency & African-American Female & \\
\hline City License Provider & Caucasian Male & \\
\hline Private Counselor & Caucasian Male & Wave I \\
\hline Public Mental Health Provider & Caucasian Female & \\
\hline Women's Health \& Shelter Program & Caucasian Female & \\
\hline
\end{tabular}

Criminal Justice Street Level Participants

\begin{tabular}{l|l|l}
\hline City Attorney & Caucasian Male & \\
\hline City Building Inspector & Caucasian Male & \\
\hline City Licensing Agency & Caucasian Male & \\
\hline County Juvenile Justice & African-American Male & Wave I \\
\hline Neighborhood Improvement Organization & Caucasian Female & \\
\hline Portland Police Bureau & Caucasian Male & \\
\hline
\end{tabular}

Youth Advocate Participants

\begin{tabular}{l|l|l}
\hline African-American Organization & African-American Male & \\
\hline Court Appointed Custodian Program & Caucasian Male & \\
\hline Downtown Youth Assistance Program & Caucasian Female & \\
\hline Runaway Shelter & Caucasian Female & \\
\hline Teen Parenting Program & Caucasian Female & \\
\hline Youth Activity Center & African-American Female & \\
\hline Youth Anti-Gang Program & African-American Male & \\
\hline Youth Outreach Program & Caucasian Male & \\
\hline
\end{tabular}

* This individual came to the wrong group, but instead of sending him away, the research team decided to allow him to participate in the discussion. 
Community Policing Page 63

Appendix C. Schematic of Research Location. Identifiers refer to seating arrangement for social service management level group.

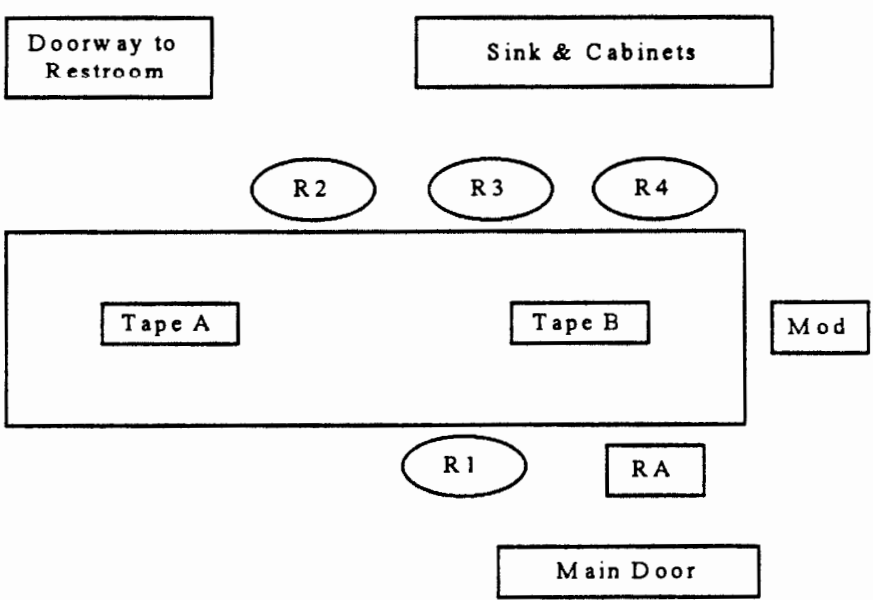

\section{Legend:}

R1-R4: Respondent 1-4

Mod: $\quad$ Moderator

RA: Research Assistant 


\section{Community Policing Page 64}

Appendix D. Transcript.

\section{Social Service Management Level Focus Group March 9, 1995.}

MOD: Why don't we start by going around and finding out who everybody is and what agency or group you're with. And sort of start to get to know each other a little.

$\mathrm{R} 1$ : Okay, My name is R1 and I am the (program name) program manager for (name of alcohol abuse program).

MOD: Okay.

R2: $\quad$ R2, I am the public safety director with the (downtown business organization). We're a downtown business organization.

R3: I'm R3, I work at (neighborhood organization) and I am a program supervisor, one of the program supervisors for the Family and Youth Center

R4: I am R4. I am the director of the (national non-profit organization)'s information and referral program.

MOD: Okay, lets start by finding...umm...out how involved you guys have been with community policing. Uh, I recognize the names of the players around the table here, but sort of at two levels: one how involved your group has been and two, how involved you personally have been. So we can sort of get the picture of what everybody's experiences are. (Pause) Go ahead, we don't have to call on people of go in circles of anything. (Group laughter).

R2: Well, (downtown business organization), since $1980 \ldots 1988$ we have had a umm street security program, is what I call it. Umm, a private security function where we are actually providing what we would call quasi-police services to the public areas in downtown. Um, the green jackets, Portland Guides and the patrol officers that support them are paid for by us and um... out there at our direction if you will... um and have seen that as ah certainly an aspect of community policing for a private business organization to take on some of the functions of the police bureau um... would traditionally been responsible for um... doing some of the things that that police (mumbled). There are unit folks out there that call our people the (private security company name) police. Um...ah... and ah... I think in the publics' mind and in certainly in our minds we are trying to deliver some of the services um... through the private sector that the police use to do. Um... (Muddled)... but um.. my personal role, um... I'm the our organization primary liaison with Central Precinct. I spend a lot of time working with the police supervisors and the line officers at Central Precinct and uh.. a good part of every week is spent interfacing with the cops in the cop shop--what they are doing and what they are not doing. How they are doing it with us and how we are doing it with them and that sort of stuff.

MOD: Okay.

R3: Ah... (neighborhood organization) has a neighborhood family center located in the (neighborhood name \#1) neighborhood which is, for those of you who don't know, is 


\section{Community Policing Page 65}

about (street names that border neighborhood) in Southeast Portland and has had a pretty close relationship with community policing out and with the safety action team placed out in that area. Um... to what we consider to be a great relationship. It has worked very well. Um... it has however sort of ended (laugh). The um... my personal ah... role at the agency is I work with the diversion program who get misdemeanor and status offense youth from the juvenile court and we work with them to set up community service and get involvement into the family and I have actually had very little contact with the police. Most of my contact is through the court. So parts of my agency have, have a very close relationship, but I am not and I don't (laugh). So.

MOD: Okay.

R4: Um.. I guess as an organization I'm not sure my organization has had much to do with community policing. Personally when they were looking at setting up community policing they understood that a big component of it is the information and referral piece that officers need resources. So I sat on the committee that helped design the in-house I \& $\mathrm{R}$ piece. Um.. and continue to work real closely with the staff that do the information and referral for the officers and the creation of data and how that is disseminated.

R1: Well, (program name) works hand in hand with ah community policing. They help us out and we help them out in in the nature of our work is picking up inebriates ah.. off the streets of Portland and downtown, Southeast, Northeast, Northwest. Ah... we've had an excellent relationship with them since they came into being a few years ago. We've had our numbers drop dramatically. Our statistics tell us something is working. I don't know if it's the (program name) outreach program or whether it's the combination of community police and the (program name) outreach program and ah... (downtown business organization) and (private security company name). Ah... but, probably all of those things come into play. So, ah... we're a big supporter of community policing. Ah... we see, especially in the Old Town area, when the bicycle police were out ah.. they could they could pick up a drug bust like that in nothing flat I mean do a drug bus tin nothing flat. That was part of the program. The horses are out now, ah.. (pause) but I see them as a real benefit. They help us with our particular clients and we certainly help them. They call us all the time. (pause) I think it is a good program.

MOD: Why don't I have you just pick up on the next piece is the question of how well informed your agency is or how ah.. whether you feel like the police make an efforts to keep you guys informed about what they're doing and how what directions it might be going.

R1: Informed? Ah... (Group laughter). I suppose they do ah... I'm not out on the streets a whole lot

MOD: U-huh. Yeah.

R1: I'm in my office, but my staff have a lot of communication with the police and ah.. they probably keep them informed which doesn't necessarily mean that I'm informed (group laughter).

MOD: Okay, that's just the kind of thing we need to sort out. What about anyone else in terms of how well the kinds of contacts you have and how well informed your agencies are, what 
the police are doing.

R3: For (neighborhood organization) it it started it started out as a very a very good relationship. They are in the process of, (neighborhood organization) is in the process of building a neighborhood family center where families in the neighborhood site could come and get clothing or child care services. It is particularly targeting families um... with children three and under so there's nutrition and we had a health nurse and AFS worker and um.. so they could come to sort of one central location and get a lot of their concerns met and addressed and the safety action team in the (neighborhood name \#1) neighborhood was ah.. very much involved in that. And there were two officers, Officer $X$ and Officer $Y$, (group laughter) and everybody knew $X$ and $Y$ and so they could it was a very positive experience for the community because these officers could walk into the school and not everybody you know headed out and turned their heads. They just, they had a lot of experience with the police that were not strictly criminal activity. These were men who got involved in the community in other ways and so ah.. people would come up and ask them for extraneous things and they could make it happen. They also actually used bicycles a lot just to to patrol around the areas and talk with people and be out an available so that relationship really grew and it was very strong. Then they shifted and decided to not do it that way (laugh) and it then started with a county and a city person and then it went and then it went away. The um.. county officers got transferred to the city about a year ago and it's.. they not choosing to operate it that way anymore. So...so, unfortunately our experience to this point is that there may be a police officer that is targeted for a specific neighborhood, but they also have a lot of other responsibilities. Ah... and so people aren't building that relationship with the police department and some of that trust that was there is breaking down. So, what started out as an extremely wonderful thing is starting to sort of deteriorated and go back to the old way and it is something that my agency is quite distressed about because there was a lot, as you experienced, (referring to Rl) a lot of things started to reduce. You know, ah... crime was lessening and and proactive ah... prevention thing were starting to occur. Um.. and the unfortunate part is that that is not as much the case anymore.

MOD: Okay. What else can people say about kinda how well informed you are and what the experiences have been?

R2: Well ah, I think that probably unique to the city just because we are able to marshal a significant amount of resources privately with our organization we have more of a partnership with the police bureau in an operational sense almost. And I think that downtown central business district with programs like (program name) and (mental health outreach program) which is a program of Mental Health Services West um.. that is um.. outreach ah to interface with people with chronic mental illness. Um.. you look at ah... um the central business district and you've got um... (program name), (mental health outreach program), ah.. (downtown business organization) folks and the Portland Police Bureau all working on what I would call order maintenance issues in the central core. Um.. downtown is sort of the crossroads of the city um.. it is a collecting point for all kinds of people. Um.. ah.. rich, poor, honest, dishonest, um.. homeless, housed, chronically mentally ill, healthy, substance abusers, um... managing that environment um.. is something that I.think from our perspective, the police have um.. certainly opened their arms to these other non-profit entities like (program name) and (mental health outreach program) and us to help them manage. They recognize that they do not have 


\section{Community Policing Page 67}

enough people um.. and there are too many of the um... ah.. folks who exhibit deviant behavior if you will for them to all the behavior management that they that is out there to be done and problems to be addressed in terms of those types of people who are acting out and so I say that there is a very close working partnership um.. both on the street and the operational level in terms of the street officers communicating with our people out on the street assume with you guys, (ON: He is referring to Rl) I know we are talking to you guys all the time as we are with the mental health workers and then on ah... the quote unquote management level um.. or the community organizing level which is part of my function with (downtown business organization). It's working with citizens and police on problems um.. we are always in contact, we are always talking about what is going on. And that is something that has evolved over the, l've been doing $t$ his job for six years now and in the beginning it was pretty hit and miss and now its pretty consistent. So, ah. I think it is working in a way that ah.. when I started doing this stuff I didn't think it ever would. (Pause). But I think, if I can just interject, I think I think it's it's just as much a fact that the private community is bringing resources to the table as the police bureau. If it was just up the police bureau to maintain the contact, the communication lines, etc. etc. I don't think it would be working that well.

MOD: Okay, that's definitely something we got on the agenda so it is a point we want to come back to. R4....

R4: Um, I guess as an organization again, because they don't interact with it, they are probably not well informed and I am only informed with an minute piece of it. I would say probably not real well.

MOD: Well, I'm kinda curious piece is the information and referral side. Do you feel they are missing some opportunities with the (national non-profit organization)? Or is that just kind of a natural.

R4: It is an interesting, I mean when we first set this up what we continued to hear because we had officers sitting on this committee is: We're not social workers and we don't want to be social workers. And I think there is still some real resistance to that piece and utilizing social services and my sense is also a real resistance somewhat to... to want to set it up internally versus accessing external sort of things that are already in place. Um. (mumbled) the Family Services unit um.. instead of utilizing family services that are already in the community and those sort of things. And setting up I \& $R$ internally versus utilizing what was already in place. Yeah, I think there has been some resistance in a way. I think they are getting better at it um.. but there is still some resistance.

MOD: I need to follow a little bit more what your saying like the internal external side. Or ah... help me understand...

R4: I think, I think, the tendency with the bureau has been to set up programs in response to community needs internally as versus putting those resources into existing systems.

MOD: Okay.

R4: I think the domestic violence unit I think is very good, but there were things in the community that could have taken those resources and utilized them and done the same 
things for them. Um.. so I think there has been a real struggle with them to want to do it themselves versus looking outside.

MOD: Well, the social service side anyway.

R4: Right, right on the social service side.

MOD: $\quad$ R3, I see you kind of nodding on some of these points.

R3: Well, I... I think... I think there are things that exist so that the police officers don't; necessarily have to be social workers um.. and that partnership in the community is one of the strengths of what community policing is supposed to be about. Ah... and it... it is sort of a sort of just from a financial dwindling resources kind of thing that ah... that partnership... people are being forced to look at partnering with other agencies and other organizations in ways they never really been forced to do before. People say, "Oh yeah, that is a really good idea, but well we can probably do it better." (Laugh). And then would probably create something and ah... it may, I don't know what kind of process the police department went through to look at in this case the Family ... What did you call it? Family Services or the domestic?

R4: Yeah, the Domestic Violence Unit which has officers just assigned.

R3: And I don't know if they did like looked at the community and said, "What is there?" and we are going to fill this gap or just why don't we just recreate something that already exists.

MOD: Well, a couple words I heard that you just mentioned and other people have are partnership and relationship. Maybe if the partnership is the formal side the agency kinds of contacts and the relationship is more the interpersonal... the person to person contacts. I'm curious, anything you could tell me about either those partnership or relationship issues. They seem like they ought to be crucial to community policing, but how do they work?

R1: What I've seen, I belong to the Central Eastside business district, they have a community policing and we have police that come to each meeting and talk about what they are doing in the neighborhood and listen to business people and you know, their needs and then they respond to them. I think there is a partnership level there as long as, as well as a relationship with these folks. I know where (alcohol abuse program) is located we have a lot of.. we have drug deals... right outside my office window and expressing those concerns to the police. You know, they have responded. It has been a financial thing for them; however, they have added some more police over in that area because the business community put up a cry for help... um... because it was getting so bad with all the drug deals that were occurring and ah.. they listened to them and they found money somewhere and added more police and the problem is being reduced. Ah... downtown you know, my (program name) staff clients, there is a relationship there um.. we go to meetings occasionally with police you know.. to deal with a certain situations and that kind of thing. So there is, I guess there is a formal partnership agency to agency, but more of a relationship then then a formal partnership. I think the formal partnership is understood. It just exists, and then what we do is really down to the reality. You know, person to person, interpersonal kind of things: solving problems and dealing with situations. 
R4: It's unfortunate that we don't have somebody, I, I'm glad R3 is here because she is at least a little bit out, but it's unfortunate that we don't have somebody from farther out because I think the difference is real different between core downtown and once you cross that river and across that community policing sort of visibility (mumbled) downtown and even inner northeast. I think, I mean I'm a resident of East Multnomah county which is annexed into the City of Portland, I couldn't tell you anything about community policing in my neighborhood. (Laugh). So, I think there is a, granted that's because those were core areas where there were a lot of problems, but I'm not sure community policing is consistent across the county either. Um...

R2: Well I think you have to recognize that the police bureau is really um.. five police departments. You've got five precincts with five commanders with five command structures and each of these people have a personality, management style their management team has the thing and um... the environment that they are doing community policing in varying in that Central Precinct has... Central Precinct has an extremely diverse clientele if you think about policing the central business district, policing Northwest Portland with its industrial districts and its highest density residential neighborhood in the Pacific Northwest and then suburbia inside the city... city line which is Southwest Portland is in my mind. You really got three different environments there for one police bureau segment to police. Um.. out in East county you've got a more, I think, homogeneous kind of environment, but it's a it's different still from what I described at Central and I would I would not hold myself out as having any kind of experience or expertise in terms of what is going on with community policing outside of Central Precinct and yet I know that many of the problems that we are dealing with down here are mirrored in the Central Eastside industrial district and over in the Lloyd Center, but those are covered by three precinct with three commanders and three management styles, so um... it's really hard to talk about community policing as a monolith because the bureau isn't and I think you need to recognize that ... um....

R4: But, I'm not sure shouldn't be if it's from the top down it should be consistent. I mean if it's across the board the mission all of those things should be consistent.

R2: Well, I think that the mission is consistent in terms of the the to of the rung is saying you will do community policing, but what that means ah... for example, a (program name) program would not work in East county. Um.. there isn't a population density, you don't have the density of the publicly intoxicated person staggering around that would make (program name) work as (mental health outreach program) for chronically mentally ill people. It just wouldn't work. So, when you talk community policing, um.. in the central city here, you are talking about partnerships between non-profits and the public side that are trying to address these kinds of street issues. Um... the issue out in East county I assume is car prowls around Clackamas Towne Center and um.. Mall 205, um... residential burglaries and things like that which are different kind of problems than... (interrupted)

R4: Homeless camps, I mean you still have those sorts of issues out....

R2: Well, I'm not saying all the issues are different, I'm just saying that if you have 100 police officers in each of those five places what are they going to spend most of their time doing 


\section{Community Policing Page 70}

and if you're in Central Precinct you're going to spend most of your resources dealing with inner city urban problems and if you're in East Precinct you're going to spend your time dealing with what are more like suburban problems um.. and um... the tactics are different, the allocations are different, resources are different. That is you know, you have so many police to do so much work, to cover so much area, and it's just hard, I think. Theoretically as I understand community policing it's supposed to bubble up from the bottom, so you the community in East county should be telling East Precinct what the problems are, what your concerns are, and the commander in each precinct should be trying to respond to those based on the feedback that he is getting from you which would be very different than what Mike Garvey is hearing from my here in Central because the issues are different and the environment is different and um.. to talk about community policing bureau-wide um.. you can do it on a philosophical level, but if you talk about how it's being implemented it will look different in all five precincts. I think. And it doesn't... does that make sense.

R4: Yeah, and well I agree, but it could also pertain to allocation of resources. Where have the bulk of the resources been allocated? Um.. and I think that is an issue based on where decisions have been made or the priorities. So, you know a lot of thing Impact that.

R2: Well, if you look at the demographics you'll see that all five precincts have got roughly the same number of bodies. In fact, Central Precinct has fewer bodies than all the others, police bodies, that is correct. 1000 police in uniform today, sworn officers today. Um.. Central Precinct has got um.. under 100 um. on patrol and um.. the rest are assigned to special functions. Um.. its its not, I don't think it's really a question of resources i.e. manpower or person power which is the bulk of the police budget. Um.. I think it has more to do with um.. size of the area, density of area, how it can be done, how visible community policing can be.

MOD: I don't want to lose the relationship and partnerships, but you mentioned something that interests me. (ON: Referring to R2 previous statements) You used the word consistency and the question of what was consistent across the five precincts etcetera. And I'm just curious in terms of the different areas that you guys have encountered or anything.... What do you feel about consistency? Is that something that maybe we could use to describe community policing? Is it consistent?

R2: I'd say it would be hard to do. I find it inconsistent from officer to officer. I mean, I know street officers, I you know, I work with a bunch of them, supervisors supervisors. They all have a little different idea of what it means and when they're doin' it and when they're not doin' it. Um.... and I would think that once, you know, and I'm just talking about like I say the downtown portion of Central Precinct which I feel is my expertise is. You get across the river to East Precinct, go up to Northeast where you are dealing with, where the police are dealing with Crips and Bloods all the time. Um.. a whole different world.

R3: The consistency for me is, I agree with some of what R2 is saying that I mean think that for community policing to be effective you have to respond to your community. Um.. and your community may have different things than my community. I don't necessarily think that the populations are different. I mean Southeast has the two highest schools with drop out rates at this point. Um.. and so we have a lot of um... of the same kinds of population where ah... the area I serve is the um... river to (street names defining area) to (Z) county 
and within that area I get the (neighborhood names $2 \& 3$ ) families, but I also get the (neighborhood name \#1) families and some of the industrial area that is closer to the river.

R2:

You have families.

(ON: R2 seems to be making a point here and is almost argumentative)

R3: $\quad$ So...

R2: I don't have families. There isn't a family that lives in downtown Portland that as I would define a family: two adults and kids. I don't think we have any children.

R3: Well that's because I don't have that definition.

Group Laughter

R3: Ah... Southeast is made up of more than families.

R2: $\quad$ Sure.

R3: There's business associations, there is industrial areas, um... I work in a social service agency. I work with families. Families can be individuals, it can be people who are completely totally unrelated people. It can also be a student and a teacher if that teacher is the most important person in that kids' life. Um... and you were also talking about the Central district serving Southwest Portland which last time I checked had families living there.

(Group Laughter)

MOD: He says nah, he says that his experience is in core downtown... (interruption)

R2: Central core....

R3: $\quad$ Oh, in the core downtown. Oh okay.

MOD: I find Central Precinct as a very confusing label to me because I immediately think downtown and then somebody tells me that it covers basically all (interruptions)... all that separate.

R3: The um... I don't so I don't, I guess coming back to consistency. I don't necessarily think that it... there are parts of it that I don't think needs to be consistent because they need to be responding to what each of the community think. But, I also don't think that there has been consistent allocation of where we are going to put the emphasis because I think Northeast does get, you know..., a lot of focus and downtown probably gets a lot of focus because so many come here that live in other areas. I mean there is just a lot of movement through downtown whether you work here of live or are just here for the day. The um... (mumbled)....I had something else, but I don't remember what is is....so...I let someone else talk and I'm sure will think of it. 
R4: I do agree. I mean I think there are some things that don't need to be consistent. I think for me the piece I see as most inconsistent is the level of commitment and that is from an individual officer level. Ah. I think the commitment is there up high, but as you trickle down the level of commitment at different places lessens. Um.. and I don't know how you....I don't know if it feasible to make everybody equally committed to it, but that also Impacts how then they implement it. So.

R3: That was actually what I was thinking about. The mission I think of the Bureau is around community policing, but not every officer, not every person in the Bureau buys it and buys into it. So, those people who don't buy into it are not going to utilize it and are not going to try to necessarily build those relationships. There will be people dragging their feet about doing it and I don't think that it is a secret that some people buy it and some people don't.

MOD: Yeah. R1, does that effect how your work gets done?

R1: Well, I don't see any. We don't see a whole lot of it-consistency. I mean (sigh) between individuals all the police are very different. Ah, the majority of them are ah.. great kind caring people um.. the inconsistency would come in with those who have a problem with drunks. And there are those who have problems with the drunks for one reason or another. Ah,... that's where I see the inconsistency. Not,... it has to be on an individual level. For me, it can't be on a agency level.

MOD: One thing that could deal with that is let's say those people who don't like that kind of duty maybe they could be out in Southeast where they are a little more comfortable with the problems, the officers, they are going to encounter. R2 said some of the deviant issues that are downtown could be on Central Precinct. But, from what I heard that is not necessarily the case, the way things work, that that the comfort level or something is part of who end up where. Does, has anybody here had experience around... or how the officers get matched to the duties they do?

R2: Well, I think there is one Achilles heel right now with community policing it's the institutional way that the Bureau moves personnel, almost without any kind of (pause), certainly without any kind of... well, transfers are driven by union contracts, seniority, and job availability. That has, that says nothing about whether or not a person is matched to a neighborhood, matched to a an assignment, matched to a ah... um... set of problems. It is ah.. how long you have been where you are, where the next opportunity is, where you are on the list, the hire list or promotion list, um.. how long you have been with the Bureau in general. That's how people get moved around. Um... its antithetical to community policing if community policing is relationships, and I really think relationships are more important than institutional partnerships, um... ah.. then you know to have all of a sudden a guy get promoted and there are two vacancies one is in the neighborhood he has been working and the other is in a neighborhood across the city, and the police bureau's institutional bias is to move the person out of the neighborhood he has been in to the new one, that's taking that person that has expertise in the neighborhood as an officer and they become a sergeant and the get transferred to North Precinct where they know nothing about gangs, they know nothing about St. John, they know nothing about whatever...but ah.. the police bureau believes that you move people so that they don't become entrenched in the neighborhood and become corrupt. And then extort money from, I mean this is the institutional um... it is the way policing is... it's not just Portland this is in reaction to the 
Tammy Hall type stuff (ON: laughter in reaction to statement) that happened in New York in the twenties where every neighborhood cop was extorting money from neighborhood merchants and they chose to break those relationships by moving people around constantly so they couldn't get themselves entrenched. Well, the Portland Police are still doin' that kind of stuff even though they're saying they want to do community policing. And it's extremely disruptive to the community when ah.. you are trying to solve a problem.

R1: I completely agree. There are neighborhoods where, probably all the different neighborhoods. I think it is really important to build that relationship with the people and moving the people around all the time it is really hard to do because (pause) next week you may have somebody different who you can't necessarily communicate with.

R3: And you have to explain the entire story to them again.

R2, R1: Right.

(ON: There is lot of overtalk here in agreement to R3's statement. Many people are trying to get heard)

R3: Whereas....

(Unable to understand with the overtalk).

R2: $\quad$....the community initiates institutional memory...

R3: Right

R2: The police bureau has no institutional memory.

R3, R4: Right.

R1: They move people around for disciplinary reasons too.

R2, R3: Sure, yes.

R3: And then they move them back, like wait for six months....

(ON: Laughing in the background)

R1: Yes, they do.

R3: They wait for the fervor to die down and then six months later that officer is back in the same unit doing hopefully not the same things, but since nothing has been done but transfer them out and then transfer them back. I'm not real hopeful about that. (Laugh).

MOD: We are coming back on to the relationship side. This is something that, I know it is kind obvious that the move contact you have and the more knowledge you have the better things presumably are, but anything you can tell us about that? About the value of having 


\section{Community Policing Page 74}

these relationships? The costs of disrupting? We want to try to understand that whole piece.

R3: For me from a youth perspective, the, there is a lot of youth everywhere in this city that have no reason to trust adults because adults have hurt them in some way in the past and we don't exist in a society today where you can go to a police officer they are always your friend or you can always go to a teacher or always go to a counselor. And I think the relationships for looking at particularly the experience we had with the (neighborhood name \#1) was people were going to these officers because they had taken the time and built that relationship and built that trust. So that maybe they could look at this as an adult that could, they could bounce an idea off of, and they would see them all the time in the community. So, I think it is really important thing and I think with all the movement of the police bureau moving officers around there is no way to build that. People, adults and kids, are just supposed to trust a police officer, but the reality is that there are just too many examples of times, not just police officers, but any adult or system has been more abusive than helpful.

MOD: Okay.

R2: In the broader community, like I say, down here, this environment is a little different. I mean, part of my job is to maintain the relationship between my constituency, the downtown business community and Central Precinct.

MOD: Um-uh.

R2: I'm on my fifth precinct commander in six years on the job.

MOD: I was going to ask about stuff at that level...(cut off)

R2: I have, I honesty see myself as the person that trains the new precinct commander. They come into their position and um... I call them up and I say, "Let's go have lunch." Then I try to meet with them as often as I can in the beginning, explaining to them all the things that their people have been doing in hopes that they will not come in a turn the apple cart totally upside down and tell everybody to do something different because that happened the first couple of times. And it was like... of we are not doing that anymore huh? You know, really,... um... and have had communication directly with Moose and have come before him and sort of said, "(downtown business organization) doesn't think it is paying me to train you commander, but I'm doing it. And we might start sending you a bill if you don't start figuring out a way to start doing it that doesn't take up so much of my time." Um.. sounds like a gripe, but that is true in any neighborhood. In any neighborhood, you know, any neighborhood response team, you know, a neighborhood association that has neighborhood liaison officer for a couple years and all of a sudden he is transferred and a new person comes in. There is no system in the Bureau for transferring the knowledge from the guy going out to the guy coming in. If the guy going out cares enough to sit down with the guy coming in, and it might be a woman, you know, and educate them, then that neighborhood has really benefited in a way that is not the norm because I have seen those changes take place so many times and it's, me and my staff that do the training, the orientation, the bringing people out to speak.

R3: And the incoming person may or may not agree that that is the way to do business. 
R2: Absolutely. Absolutely, and its very difficult to have a project in place and say this is what we have been doing and have the new person come along and not have... dittily interest in continuing the status quo. Even if you think the status quo is very successful.

MOD: It can't be a surprise to you that you are not the first group from which I have heard this. (Group laughter.) But I just find it incomprehensible that, I mean I don't understand how under community policing (mumbled) you can keep community poling going with that much instability, lack of transition...

R1: I think it is because all the rest of us to there working with them do exactly as R2 said. We train them. We train the recruits. They come to (alcohol abuse program) when they are in the Academy and they have time spent at (alcohol abuse program) to find out what we do, what the (program name) program, what the sobering station does, Detox residential program does. And, so we train 'em.

R2: $\quad$ And the beat officer that shows up, you train em' on the street probably.

R1: $\quad$ Sure. Every time we meet up with a police officer that we don't know, who's got somebody, you know, waiting for us, we train 'em. Right there on the street. This is what we do, this is what we don't do. This is what we expect from you and this is what you can expect from us.

R4: I think the training piece is the key to community policing. The problem is that I think that we spend a lot of energy doing just that. The training that maybe should be spent in other places. I'm not sure that there shouldn't be a better way. It shouldn't burden the human services part which is already overburdened. I'm not sure there shouldn't be a better way.

MOD: Well, training is definitely on our list. Why don't we go ahead and talk about that in terms of... its something that you would figure with a community policing model the training would be conducted different or there would have to more areas of training or what... um... is that anything you can tell us about? What the training aspects of community policing are, that would be helpful.

R4: I think they try... they are trying to make some changes. I mean, still at the Academy level, the official Academy in Monmoth there is very little human service training. It is all... it all happens back at their special academy here. Um.. so there is not a whole lot of exposure to human services in general um... and I think its fallen to each of us. Anybody that gets invited to train at the special academy to educate um.. but I'm not sure they have given a whole lot of focus to the human service training piece.

MOD: Okay. So there is a stream of training. This is, as many times as I have heard people talk about community policing you have raised a whole new dimension. Everybody is talking about the training that is done in Portland as opposed to whatever it is at the Academy.

R4: Well, yeah, Portland police have... I mean there is the State academy in Monmoth and then Portland officers come back and have special training that is over and above that. And I don't know how much of that is dedicated to human services. My sense is not a whole lot. I know the I \& $\mathrm{R}$ piece is only a few hours at the special academy. So.... 
R3: Is that when they come to your place, the Portland Academy (ON: referring to Rl's statement about officer on-site training).

R1: Yeah, they don't come up from Monmoth. They are out here. They have been on the streets for maybe a year or less, but they are in the what you called the special academy.

R4: Yeah... I think that's the word for it-the special academy.

R3: So, its sort of on the job. While they are doing the job they are expected to come down and spend time with (interrupted)

R2: They go through the Academy and then they are trainees: Phase I, Phase II, Phase III. Phase I is probably when they are working with a coach and they got an experienced officer kinda leading them around and showing them what is going on and that sort of stuff. I think there is a limit to the amount you can absorb at the Academy and the kind of work that I think the officers have to do um.. ah... I think you learn it best when you are doing it um.. and sort of on the job. That is the way I learned my job you know, when I started working downtown Portland I didn't have any experience working with the cops. And um.. I just kinda picked it up through trial and error and a lot of repetition and I think that while you can do classes on how to deal with a person that is intoxicated or a substance abuser you know, what to look for, what to do, what not to do. It really on becomes real to the officer when they run up against the first person that is collapsed across the street and trying to take what they remembered and try to apply it. You know, figure out what works and what doesn't work. Um...

R4: What I think they do lack is communication training.

R2: No question about that.

R4: $\quad$ So what they have never been taught. How do you communicate with somebody that is a substance abuser? On the domestic violence stream that it is not unusual for a woman to go back and forth several times before they leave him. What you see then and the interaction I have with officers who after the second time the woman's $g$ one back the officer's written them off because they don't understand what the norm is in the domestic violence situation. Or, when they run into somebody that is mentally ill, um.. and I know they are really working on that piece. What do they do with them if they don't know what their name is or where they live? And they are really putting (mumbled) emphasis on that and I think that is really goo, but they have not been taught any communication and from the social service side...I mean if your a social service (TAPE TURNED OVER). my husband is a policeman. So, my knowledge of police comes from both sides. The human services side and being married to an officer, so.. um... I think there are some real issues in the communication.

MOD: Okay. What else about anything on the training side?

R2: Um, I don't know you know, its it the issue of people with chronic mental illness is a hot one in Portland this year.

R4: Yep. 
R2: A couple of people have um... engaged in police assisted suicide. Um... or whatever you want to call it. Um... and it's I guess it's hard to imagine (sigh). I know that the police bureau has put I think it is four hours of their ongoing training um.. in a given year into trying to help officers to develop skills dealing with people with chronic mental illness. My spouse is a registered clinical social worker and I'm not what you can hope to teach a police officer in four hours you know... in terms of really giving them any clinical skills for dealing with folks other than the very barest rudimentary minimum stuff. And um... I guess it's to me, just sort of emphasizes the difficulty of the job, the amount of stuff these people have to do, the amount of skills they have to have, and their ability to switch from interacting from you in your suit to the guy that comes out of the store stinking of alcohol and falling down, to the kid you know, coming off the bus that looks like he has a gun in his pocket. You know, it's a job I couldn't do frankly. And um...

R4: I, I think you are right. I think the key isn't (MN: the recording is muddled here. It may be is) to train everybody, but I think there are those officers that would be very good at it and I know that have sent some people back to Memphis to look at a model back there.

R2: Yes.

R4: And they are going to potentially open that up to officers that are interested in becoming good communicators so they don't have to shoot people any more. And I think that is the key, that's the key to targeting those people that really have an interest or a skill in dealing with substance abusers or whatever and utilizing their skills instead of looking across the system to teach everybody.

R3: I think that the key, a key, is also the ongoing training that you can only gleam, as you were saying (ON: referring to R2's earlier comment), so much from the classroom that you really kind have to out there and. Cause there are so many things that just in a classroom you are reading, oh yeah that should work, and you try it and .... (Group laughter)... no wait, you're supposed to say (group laughter).... and they don't, but that ongoing training then once they have tried it and sort of found something that works for them, but also going back and doing that continuing ed. because as you are sitting in a classroom and you have had experience you can think, "Oh, I had a client like that or oh, I had an encounter like that and this might have worked better." And so it's kinda doin' it from both ways that... and learning to blend that together and not just assuming that the education, the formal education stops once they hit the streets.

MOD: We are getting into an area that R4, already tapped a little while ago. I hear a lot of things that kinda come into the question of who does what between the community and the police. And community policing blurs those lines and hopefully in some positive ways but also possibility in some confusing or counterproductive ways. I'm wondering what sense you guys have about with at least the way we're doing it here in Portland, how do we straighten out those issues around who does what, particularly between the police and the social service agencies?

(Pause)

MOD: Uh-huh. 
R4: (Laugh). I guess as R3 said, I'm not sure how they decide whether they do it internally or whether the go outside. I don't know what their process is, but it would seem to me a process that brings the special groups, the specialty people, whether it's Domestic Violence or whatever to talk about what's the best way to do it. It is the ongoing open communication between social service agencies and um.. law enforcement. It's all social service agencies, I mean the churches in this community play a key role in social services and I'm not sure that they have any relationship to community policing. Ah... it's a very big system and not sure how to merge the two.

R2: I know that they do in Northeast.

R3, R1: Yes, they do.

R2: I don't know about the rest of the city, but (ministry outreach) is very involved with the whole effort in Northeast Portland (pause). And the mission from downtown in very involved with the police and all that...

R3: I think that is part of it. It's just to bring people to the table and say, you know, identifying your concerns and finding out who wants to take um.. take part in a conversation, take part in a solution. I think it is also acknowledging the expertise of everybody. I think there are a lot of times that when the police become sort of the bastard stepchild and can do nothing right um.. and people... I've been in groups where it's just like... they are just pounding on the police and like wait a minute. You know, part of a partnership is that the community (interruption)

R2: ...some responsibility

R3: Right, and everybody sort of wants the police to take care of things. And the courts to take care of things. That a lot of what drew up ballot measure 11. People don't want to get involved they just want it taken care of. I think that part of community, good community policing is community and getting that community to take.. to be accountable and take some of the responsibility in that. Um... but it's also (mumbled)... a lot of times to community and the homeowners and the business people have a lot of expertise that go untapped, as does the police bureau.

R4: Yeah, I think social services need to take some responsibility to. What we heard initially when we were talking information and referral is, "We don't want anything to do with this as a social service agency because we can't handle any more. We already got more than we can handle. We don't want officers handing us another 200 people to us. And that is the reality. The social services system... but it's also our role to do that... figure out how to find the resources to do what needs to be done so, and maybe jointly that can happen.

(Pause)

R3: Finding a way to tweak the system.

R4: Yeah.

R3: Maybe the way I am doing it now is that I can only take 100 kids a year or 200 kids a year or whatever and be willing to lay the system on the table and say, "Okay, It worked for the 


\section{Community Policing Page 79}

first ten years, but that doesn't mean it's gonna work for the second ten years." And, and how we can make those adjustments.

R4: And Measure 5 is gonna make us do our business better anyway. Uh... we are going to have to.. uh... because the resources are going to get scarcer and scarcer so.

Mod: What else able this who does what piece? What can you say about that?

R2: I think that the police bureau... ah.. community.. the biggest part of community policing is supposed to be the first word-community. Um... the skills that I think that um... that many officers don't have that I think there is fairly broad recognition that they don't have it. And that's good. Is how to organize the community and so, my perception in six years down here has been um.. an increased recognition by the bureau personnel that they need to involved the community in problem solving, but they don't know how to do the outreach and find people. And they have figured out who in their jurisdiction does and they are utilizing those resources. And I am speaking mostly of the neighborhood offices and the community organizers that work for the neighborhood association system. Um.. that's been a change. Six years ago officers use to call me up and say this is how I am going to solve the problem. What do you think? And they would think that by talking to me they were doing sort of outreach to the community because I worked for the private sector, the business community, and I related to the rest of the downtown community and I always had to say, "Well, you'll probably need to go talk to this group and then to this group and then to this group. Or, I can help you pull together a meeting with representatives from these three groups and you know, we can talk about the problem." That's the way you are going to involve the community and that's how you are going to be able to say you are doing community policing. Is that sit down with these people and figure out $\mathrm{A}$ ) if the problem you have identified is a problem they are worried about.

R3: Exactly.

R2: $\quad$ And then B) if there is consensus about that, what can they do to help you. Or what do you want from them and that sort of stuff. In six years, that's... going from where I was sort of having to keep reminding people that that is what they needed to do, they now know that. I see some real movement. From my own experience has been um.. ah... a tremendous amount of incremental change in how the Bureau is um... doing business and um.. as I have gotten to know the Bureau and understand the culture to realize how far they have to go. I give them a lot of credit for having been able to go as far as they have gone in five years. And.. and.. ah.. I was just saying to a reporter from the Willamette Week the other day that I think that the police bureau is doing a terrific job of trying to institutionalize community policing. Is is not all there yet, it's not perfect, but you are going from a quasi-military organization five years ago where it was all top down.

Nobody on the front line thought um.. they just followed orders. To an institution that has really gone a long way to change those norms and morays and um... it's it doesn't look like to institution it looked like five years ago. I don't think it could be the institution it was five years ago now. I really think that it's so institutionalized at this point that if a new police chief were to come in tomorrow and say, "Forget this community policing we are going to go back to the standard stuff." I don't think they could do it. I don't think that the rank and file would follow. 
Mod: That is a real question that I've got. What is the role of the police, particularly police in leadership in community policing? I mean I sometimes here that, in fact I heard it today, that the top down associated with this and but, it really leaves open the question of how much of the initiative and the direction for community policing comes from the police.

R2: Down here I would say it's about half and half. I mean in terms of our relationship probably half the time I am calling Central Precinct and saying I'm hearing from my constituency or I'm hearing from somebody that this is a problem. Let's go to work on it and probably the other half of the time I'm getting a call from somebody from Central Precinct saying, "We think this is a problem. Would you help pull together a group of people so that we can talk about it?" Um.. it's really pretty fifty fifty in my experience. I don't think that it is that way every place, but in downtown its... its... like I say, an amazing partnership that we....

Mod: R1, your another downtown person, what is your experience?

R1: Uh... I don't know. (Group laughter). We actually deal with three precincts-Central, Northeast and East.

R2: That would make you schizophrenic.

R1: So, (sigh) I really don't know how to answer that question.

Mod: How about on the Central Eastside thing? How much do you have a sense that you are coming to them, they are coming to you?

R1: I think as far as the business district goes over there, they're going to them and in response the police have started coming to their community meetings, their business meetings, neighborhood meetings. I think that .... most of the neighborhood association meetings have some kind of police representative at their meetings.

Mod: Uh-huh.

R1: And they are well attended by neighborhood people or businesses wherever the neighborhood meeting is going on. I think they work well together that way. They identify problems together, they can, they can work on solutions together. I know the Northwest neighborhood association is extremely active uh.. with community policing. Um.. I don't know about the other neighborhoods. That's about all I know about it really.

R3: For me, I think in Southeast there are a lot of neighborhood associations that fall within just our (mumbled) area on out to the point that (neighborhood improvement organization) has done a lot of coordinating and working with the Bureau and the neighborhood. The ah.. lack of involvement I think that comes to neighborhood associations, I think sometimes neighborhood associations can fall stagnant because neighbors don't get involved and so you get the same dozen people that are coming. Um... and if you only listen to neighborhood associations you are going to identify one or two problems. Um.. and think that the entire neighborhood is concerned about that. I think that the Bureau, our with our neighborhood family center, in (neighborhood name $\# 1$ ), really put a lot of effort into finding out what were the concerns of all of that community and came up with ideas to try to meet that as well as were willing to scrap 


\section{Community Policing Page 81}

ideas that when the neighbors said, "Well that's a lovely problem, but we don't care about that right now. We are worried about um... we're worried about these gangs, we're worried about what is going on in the park or wherever." So, the police bureau at that point did a lot of outreach and a lot of coordination in trying to meet that. Um... and then I think it got hit with the moving around and those officers left and that particular office for the safety action team shut down, and that is just sort of the end of that.

R2: You also had a change on command.

R3: $\quad$ Right. Yes.

R2: The precinct got broken up with East precinct then became Southeast and East. So, all of a sudden...

R3: I think people don't know who, I don't think they know who their contact person is. I don't think, I mean, I know there exists a contact office, but I don't know where it is. Um.. and from what I understand from people is that should they try to go there's usually not even an officer there. So... if you can actually find an officer... you know.. so if you find an officer there you are lucky. You have really hit because they have so many other responsibilities to take care of. Um.. and so I think the building... that they took a lot of time and effort into doing for several years they also ended up effectively sabotaging... I don't think they meant to do that they just...

R2: That's the way the institution works...

R3: Right. And that's just what happened. And I don't have a lot of.... I had some contact with some gang enforcement team officers.. um... but I pretty much seek that out if... and for me that is an appropriate thing. I mean I don't necessarily expect a lot. The most contact I have ever had personally with the police bureau contacting my agency was (mumbled).. we want to do this is when they want to directly bring kids to my center and drop them off at the center instead of at the court which is a system they used to use about ten (ON: maybe she said two) years ago maybe a little bit more than that.

Mod: This is the diversion piece?

R3: Through the diversion piece and uh.. and... we haven't done direct diverts in years and um.. I mean I have a procedure thing that says how to do a direct diverts should someone actually show up on my door, (group laughter), that I keep in case someone shows up on my door. That is not something that is currently going on. Um.. and its mostly, would you be willing to do this, and it's like well um... you know... I'm not going to agree to do it right now I'm willing to have a conversation about it and see what we can do and then it dies.

R2: $\quad$ Cause you didn't do it right now.

R3: Right. Um... well its like I'm a little busy right now, but we can certainly be willing to have a conversation and then it poufs away for another year until someone calls my the following year. Usually someone new who has been transferred into that position.

(Laughter). 


\section{Community Policing Page 82}

Mod: (Mumbled) let's do a little role play here. Your probably have a boss or a director or something.

R3: Uh-huh.

Mod: Suppose that person comes to you tomorrow and say, "Things used to be a lot better in the days....back in the days of Officer $\mathrm{X}$ and $\mathrm{Y}$. R3, we want to do what we can to put that back together. I'm going to put you in charge of that." Can you begin to imagine what you would do from your end as a piece of the community to... try to?

R3: Actually my... I'm very fortunate because my direct supervisor is the one who got that project going out in (neighborhood name \#1) Center. She has already been through that path, been down that path. I would be able to say, "You know, whatever, of course, great, I would be happy to do it and I have the time. (laughter). And I have lots of time and I'm so thrilled about it." And then she could pretty much tell me how to do that. Um... the ah... so I would be fortunate to do it.. I would presume.. and having watched one of our community developers go through this for me it's a lot about just doing what you are talking about. Going to each one of these places and finding out what are their concerns and its saying what are you willing to contribute to that. To try positive (mumbled) that we are trying to make and finding out what you would be willing to bring and what you would be willing to bring. Well, RA can bring this, would you be willing to bring .... and just doing a lot of foot work through out and seeing what is there. And watching him do it... and watching our community coordinator develop in such a way so that every person at the table ends up sort of thinking it is their idea and so they have a lot of passion about it and that can be really hard... hard thing to do and not necessarily a skill I think I have. (Laugh) Um... because that's when people will buy into it. Is when, when their, they really think it is their idea and they can own a piece of it.

Mod: Okay why don't' we...

R3: Does that answer you question?

Mod: Yeah it does, it produced more questions, I'm sorry. (laughter). In a sense you are telling my the knowledge is there in the agency. It sounds like the motivation and valuing of that kind of thing is there.. um... so.. why didn't it get put back together?

R3: There was nobody, at least there was nobody in the police bureau to respond (Group laughter). It essentially got disbanded. Um.. and so there was no there was no contact person there anymore to help to continue the relationships. Um...

R2: Did you guys try though?

R3: Um.. actually I have no idea. I would assume because it was such a it was such a strong component of that relationship, but I'm guessing. Um...

Mod: It could be to like R2 says that the new commander comes in and says that ain't happen' and so there isn't much you can do. Okay..

R2: Well, you can jump over the commander's head though and go to the deputy chief and say, "Deputy Chief, this commander doesn't like our neighborhood project and we like it. 


\section{Community Policing Page 83}

Why don't you tell this commander that they need to value our community policing project?" You always use those words-community policing project.

R3: Well, I think there are different definitions of community policing and how to implement it.

R2: That's true, yes.

R3: And the style that was being implemented is really more the Multnomah County style and and Portland has a different of doing it which is not necessarily ... I think in my agency's opinion doesn't work as well. Ah.. it has more inherent barriers to work around.

R2: I'm guess I'm just suggesting.. (interruption)

R3: $\quad$ Right if you don't like it (interruption)

R2: If you had something that worked, if you want to play the game and this is this is I guess one of the ironies or inconsistencies of community policing because it is supposed to be bottom up and when it doesn't work that way if you want to play politics in the traditional way you can make it.. you can at least get them to the table by going through the old top down. Talking to Roberta and telling Roberta to talk MaryAnne and MaryAnne talking to her lieutenant and the lieutenant will then send somebody to talk to you. They may be a blank wall (group laughter) and that is very possible, but you may get lucky you know what I mean and that officer might be, "Oh wow, yeah, let's do it" and off you go.

R3: It was the.. that particular unit ended up disbanding when the county officers... (interruption)

R2: The safety action team (interruption)

R3: And it was a real it was a really balance in our agency because one part of our agency was going to benefit from that transfer and one part was not and was going to be harmed by it. We all.. within our agency said, "Okay, this is the way it is and what are we going to do? We just kind of said you know... you are my boss.. you go do your thing and advocate for what you need to advocate for and I'll go do my thing and advocate for what I need to advocate for and we'll just see what happens." And.. no ill will between us and it was a really weird thing because we always knew that if we supported one position (ON: can't understand words here due to coughing on tape) not supporting the other one. It was not a fun time.

R2: It doesn't sound like a win-win.

R3: No, it wasn't, not for our particular aspects at that time. So..

Mod: Well, what I have been looking at and have been wanting to hear more about and we can open it up beyond that and your experiences is the question of what is that (not understandable due to coughing) is community policing. It is always been to me what the community's role is? I mean we have Chief Moose that can tell the police or Vera Katz can tell the police what their role is, but how do we figure out what the community's role is? How is that get straightened around? Why don't we start by just going around. 
R4: I was just sitting here listening to people and thinking we've probably as a community made them fairly schizophrenic too because I can see that there has probably been a lot of pulls in a lot of different areas and not necessarily a process internally to decide where to pick which one of these because everybody, if you talk to anybody, every neighborhood has something they want from community policing and um... and also I think in social services we've not always been real responsive when we've gotten that call from an officer that says, "This is what I've got." And our response is, (interrupted)

R2: Tough. (laughter)

R4: That's right. That's right. And truly you only get one chance with an officer (interrupted)

R2: Oh! That's for sure.

(ON: There is a lot of overtalk during this time. I am focusing on the primary speaker and not the affirmations interjected)

R4: You blow that chance they will never use you again and we've not gotten that message (interrupted)

R2: It's called one strike and your out.

R4: That's right or um... you give them bad information they are never going to use you again. So, we've not done, also in social services, we've not accepted how important it is to become part of that relationship. So...

Mod: Uh-um. Okay.

R2: I know that down here I mean if you are talking about what are the types of things that the community actually does... I mean we have citizen patrols where people who live in Old Town, work in Old Town are going out at nights on weekends with little bright colored vests and flashlights walking around creating a presence. The same thing up in Northwest Portland, the neighborhood that I live in, um... ah... in Old Town the neighbor, the community created a ah.. bilingual poster that basically told the drug dealers in English and Spanish that they weren't welcome in the neighborhood. They had in printed up and they distributed it through the neighborhood. Created a little flyer to give to people who live and work in the neighborhood about how to access the police, what are the types of things to look for, very tangible types of things that the community felt it could do that helped the cops do their job. At the same time, there's intangibles I think that just around what I call traditional enforcement issues. Um... like busting drug dealers in Old Town, there isn't much a citizen can do to help that other than make sure the commander, the deputy chief, and the mayor appreciate the efforts of the officers so that the officers hear from their supervisors that they are doing a good job as well as from the community so they can do sort of a lobbying-advocacy stick. Kind of.. you (ON: referring to Rl previous comments) alluded to the Central Eastside business people you know doing that... you know motivate the commander to allocate the resources so that the officers who are patrolling the Central Eastside were probably as frustrated as the merchants are in terms if their ability to impact the problem feel better because all of a sudden five more 


\section{Community Policing Page 85}

people maybe on a shift showing up on a shift to help them kick butt and take names (ON: R2 clapped hands together). Sometimes that's what community policing is... is getting the community organized well enough so that you can motivate traditional enforcement.

R1: The Central Eastside has done the same thing with the flyers.

Mod: Uh-huh.

R1: Um.. except they had to pull all their flyers in and replace them with new ones because they had a translation problem. (Group laughter). They actually said, " Drug dealers are welcome here. Drugs are free." (Group Laughter)

R3: Oh no! (More group laughter)

R1: We were wondering why ... I have one in my window and we were wondering why the Hispanics came and sat on the ledge outside my window (group laughter). And I found out. Now they're replaced with a proper translation. And we are in a drug free zone. Old Town is a drug free zone. That was a community policing effort.

Mod: $\quad$ Right. Right.

R1: That seems to be working fairly well. I've been in this business 7 years and on the streets the first three and ah.. and l've noticed a huge impact in the number ... a decrease in the number of drug deals that is going on down there. Um.. you know the department of immigration comes through every once in a while and does this huge sweep with the police and you know... there's another partnership there, especially in downtown and the inner Southeast area, where there are a lot of Hispanics that hang around there (muddled) and do various and a sundry things. But, yeah, the Central Eastside I know, has taken an active role in letting the police know what they need. Um... and uh.. finding out how they can help the police do that job.

Mod: $\quad$ Right.

R1: Flyers are one things they have a program called adopt a block uh... you know... they are actively taking a part and seem to know what their part is as a community, what their part is in community policing program over there. I don't know how their neighborhoods are doing that you know. When I worked downtown it's I don't' know... I don't get a sense like I do in the Southeast area. Of course we are in the Southeast area...um... I know what they are doing there. And I'm assuming (neighborhood improvement organization) does the same thing. Northwest... the Northwest area does the same thing. I don't know if that is consistent throughout the county, or the city, but.

R3: Well, Northeast neighborhood coalition has a very strong presence and a strong community tie as well as does (neighborhood improvement organization) who does a lot of this stuff. As well as, um... (mumbled) right before I came down here about graffiti removal and there has been a very large push I think in the last few years and people have really responded to understanding why it is important to get graffiti off as soon as it is on. Um.. so there has been a lot of I know (neighborhood improvement organization) has coordinated a lot of graffiti removal projects around the city and cleanups and we take community service kids there to help participate in that when those happen. So.. and I 


\section{Community Policing Page 86}

was talking with the man who was coordinating it about a year and a half ago and they did a phenomenal amount of work because you have to, if it's on a business, you have to have the business owners permission to paint on the building and paint over the graffiti and a lot of the owners are absentee and are into other States and so actually calling California to say, "Hi. You have graffiti on the side of your building. Do you mind if we paint over it?" Um.. and um getting no response or and some people will respond, Absolutely, go right ahead. Others are like I don't care. If you want to. Or absolutely not, I don't want you on my property. And its like (sigh) Okay.

R2: What do you do then?

R3: Yeah, but I think that people have really tried to look at... to look at what role they can play. I think some people have looked into what role they can play and other still want the police to take the first 500 steps (laughter) and then maybe.

R1: I think that differs you know... among neighborhoods. You know, residential neighborhoods probably don't have a whole lot of idea about what they can do. Whereas, the business districts you know, it effects their pocketbook and they get in their and start figuring it out you know. They start doing that. I mean Central Eastside had the phones removed from Plaid Pantry up on Burnside because there was drug deals going on at those pay phones, so they actually took part in doing that.

R3: I think the community knows what power they have and if they were to access it and organize it and tap into it a lot more could happen. But I think it is sort of general ignorance.

R1: Right, but then you take residential areas up in Northeast you know they have taken an active part in organizing and ah.. developing plans with the police to stop the drug house, to get rid of the drug houses and hanging out on the corners and doing the drug dealing and all that kind of stuff.

R2: I think there is a direct correlation between how visible and serious the problem is and how... how motivated the community gets to getting involved with the police. You know, my sense is that the serious crime problems in Southwest Portland, what I call suburbia inside the city limits is residential burglaries and car prowls. Those are... are very.... those are not very visible with the exception of the car prowl where the window is broken out and there is glass all over the street. Um... you know... having been victimized by that kind of stuff myself um... unless I tell a neighbor it happened, they don't know it happened. Five kids standing out on the street corner doing deals and all of a sudden gunfire breaks out... everybody on the block knows it's happen'. And that is really going to motivate folks or you know... in Old Town and there are fifteen guys standing around a corner swapping money and drugs it is pretty hard to ignore. So, when it gets really in your face, the community will gear up and do what they have to.

R3: And I think it's what they are willing to accept.. (interruption)

R2: $\quad$ Absolutely

R3: $\quad$...because I don't think there is anybody in Portland that doesn't think, "Well, my turns done." (laughter) 
R2: I hope.

R3: Yeah, but if it happens to you three times (ON: R2 is continuously over talking and throwing in affirmations and interjections) in six months its like wait a minute.

R2: $\quad$ Right. Right.

R3: You know, I've been hit more times than my turn.

R2: $\quad$ Right. Right. Yes.

R3: So, I mean we've had our truck stolen and so it's like... it was a pain and we went through it and, but we went through it and it was like okay, check (ON: R3 mimes checking off a mark on a checklist). The one stupid thing we did in that whole thing we won't do again. (Laugh).

R1: The neighborhood watch program that started years ago, you know, um... you don't here much about them anymore. All you ever hear about is community policing, you don't here about the neighborhood watch programs which were precursors to... (interrupted)

R3: $\quad$ Still exist.

R2: $\quad$ They still exist.

R1: They still exist, you know in a lot of neighborhoods. And that was.. those were residential areas that got together and said hey, we have to do something about this.

R3: As well as the block homes.

R1: Uh-huh. And the the block homes.

R4: And the block homes. You don't see much of those either

R3: And yet they still exist

R4: Yeah

R1: Yeah, but there's not a little sign in the window. (laughter)

R2: That used to be a police function. The police used to help set up block homes.

R4: Yeah.

R2: Now its...

R4: The sheriff's office

R2: Now its evolved out into the community based organizations like (neighborhood improvement organization) to set those things up. 
R4: Uh-huh.

Mod: I was just going to check on your reaction to this whole questions about what the community's role is in community policing? (ON: directing question to R4)

R4: I think what everybody said. It is our role to I think motivate things to happen. Um.. I think the community needs to take some responsibility for the community. I think for a long time we have said its a police problem. The police departments are never going to have enough resources to deal with all the problems. It's pretty sad when you see some... the one that was in Gresham not too long ago when they were taking back their community. It was like this is pretty sad when we have to make news because somebody is taking back their community um.. because we've obviously lost some of them um... it really does mean that people have to get out and get involved and if we are not going to be involved it is unlikely that the police are going to see much reason to be involved and so...

R1: I think we have gotten past the blaming of the police department stage and people are starting to stand up and reclaim their neighborhoods.

R4: $\quad$ Yes, I think so.

R1: For years, you know, it was like you said, a police problem. You know, and shame on those police (interrupted)...

R2: Oh I know.

R1: $\quad$... and it was all their fault. You know, (unable to understand due to overtalk)...

R4: That's right (laughter)

R1: I think people are finally waking up and realizing that if we don't get involved with the police that it's just not going to happen.

R4: Right. Yeah.

Mod: One of the questions that really raise for us, is with that kind of model, how things ought to happen. How do we know if the police are doing a good job or how do we know if that's working? Under the traditional model, the call 911 model, the catch the bad guys model, then you build up all these crime stats and response times and call clearances and everything else and that was supposedly how we knew if the police were doing a good job. Well if we aren't going to do policing that way then how do we know if the other thing is working at all?

R2: I think some of this numbers still have validity um... over a long term. For example, just as an example, we um.. have had this street security program out on the streets of downtown Portland for six years now and I've just been... and our people record their contacts with the community, all different kinds of categories, and I've just been crunching numbers and some of the things that you would expect to see decrease because there is a presence out there are in fact decreasing. We keep track of the number of assaults which are something that usually show sup on police reports so there aren't a 
huge number that we track, but we also track what we call aggressive behavior and both of those are on a steady consistent downslide in the area that our people patrol... um over a six year period. And yet, if you look at little chunks in between, you know like month to month or quarter to quarter um... there are up and downs, but after six years I think you can see um.. trends on certain order maintenance issues that would be impacted purely by a uniformed presence. Um... panhandling seems to be on a steady decline, um... what was one of the other ones? (pause) Intoxicated people and and substance abusers seem to be on the decline... now I don't know that you can necessarily attribute all of those decline to that the fact that we have put these people out on the streets, but I don't think that they are not a factor either. Um... so... so... I think if we continue to collect those calls for service police report type data, um... over time we will see positive trends as a result of community policing because I think that the kind of police work that community policing is does try to get more towards root causes as opposed to showing up to the place, taking the person into custody, handing them off to somebody else and getting back out in the car to take the next call. I think it does offer longer term solutions than that kind of police work.. um and I think the other way you measure whether or not it's working is just kind of... and this is the part that is hard to get your brain around um..., but and it's probably expensive is just doing a lot of work like this that is constantly taking the temperature of the community, asking people who are interfacing with the police and not interfacing with the police, what they think of how things are goin' and if people feel like they are going well, then I think community policing is working. If they don't feel like it is going well then it's not. And that is pretty mushy, but I think that's the other component to it.

R3: And I think that it involves also cititzens that aren't necessarily working in business and social service agencies.

R2: Right. Absolutely.

R3: That um.

R2: Yeah, some kind of community wide (pause) scientifically um... dependable sampling you know surveying . Um... focus groups, interviews, telephone surveys, polls. Hell, we can find out tomorrow whether or not Mark Hatfield is gunna.. um... you know um... whether or not Oregonians support Mark Hatfield's stand on the balanced budget amendment, we should be able to find out whether or not Portlanders think community policing works.

R3: I think it tracking... I mean I assume the police bureau also does an element of information and referral stuff that if someone calls in and it's this isn't really the number you needed and tracking somehow the requests for what could be termed more preventative service rather than police show up I think someone is in my house. Um... and I think it is a hard thing to do studies on just because the whole essence of community policing is relationships and partnerships and that consistency and when you get that many people involved there is no way to isolate any one factor..

R2: As solving the problem.

R3: Yeah, as being the one thing that did it. And.. because the communities are so different the tactics would be different um.. but.. looking at things like um... preventative calls and um.. and as well as I was glad (mumbled) over time that some of those numbers um.. decreasing but that it is really a time long time kind of thing 
R2: (Overtalking) Absolutely. Longitudinal.

R3: It can't, that was the word I was looking for. Thank you. (ON: referring to R2's previous statement). It can't just be just because it's down in 94 from 93, therefore community policing..

R2: Works.

R3: It could just be that they got better at it

R2: Well, actually one of the interesting things that has been a revelation to me is um.. sometimes when you... when you go about trying to solve a problem. the short term picture is that it is worse because you wind up with more effort, more reports, more incidents.

R3: $\quad$ Right.

R2: $\quad$ More documents, more number getting kicked off you know... I was talking to Central Precinct about a problem that we are experiencing along the transit mall and I asked what their arrest statistics were for 93 and 94 on a stretch of block. And um.. in 93 there were 110 and in 94 there were 40 . That would say to you that there were whatever problem was there is

Overtalking

R2: Well, in fact they ran several missions in 93 that they didn't run in 94 you know... you look at the numbers that our people generate that sort of track the same thing you see that the number.. the problem going this way from 93 to 94 so, so, figures lie and lies figure as you ...

Group laughter.

R2: So, you have to be very careful about how you use those statistics but I think that over a long period of time, if it works they should show some improvement.

Mod: We are getting down towards the end on time and I got to see if I can sneak a couple more questions in here. One that we're trying to ask about is if you had some ideas about some areas where community policing isn't reaching, you guys did a good job early on talking about the different parts on town. Well, what about the different clients, or different services, or different problem areas where community policing may not be taking hold as well as some others. Anybody want to nominate an areas or...

R2: $\quad$ Street kids.

R4: I was going to say youth, but street kids. Yeah..

R2: Well street kids is my particular problem with downtown, but 
R3: I think youth in general (Overtalking). Youth is the hardest sell.. and for some very good reasons.

R4: I think there are some starts by putting um.. officers is schools at younger ages..

R2: $\quad$ Police activities league

R4: DARE and that sort of stuff is starting to do it, but I think youth is really the population..

R2: They have a long way to go.

R4: Yeah

Mod: Want to nominate any other areas? Got a clear one there.

R2: My perception, and I don't know um.. this isn't from first hand, you might be able to speak to this better (ON: referring to R4) is the Asian community. What I here from people um.. that have particularly new immigrant Asian communities: Southeast Asian, Thai, Vietnamese, those communities are having a hard time

Tape Ends. A closing statement is recorded on paper. Moderator thanks group for attending and group exits. 
Community Policing Page 92

Appendix E: Example of Sequential Structure of Community Policing for a Youth and Family Center.

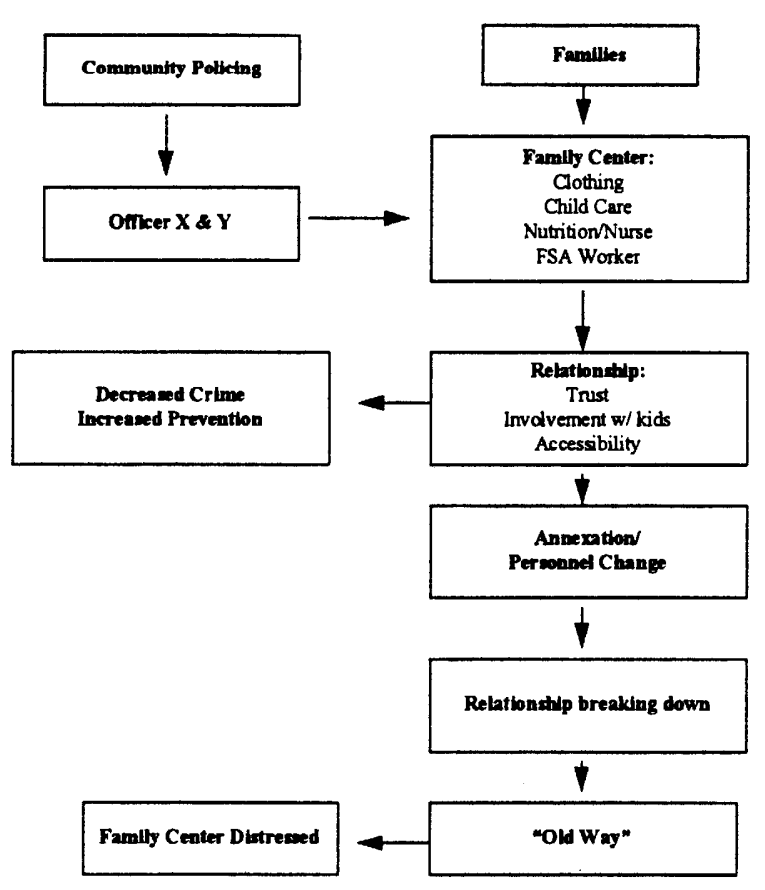

